\title{
A CLARIFICATION OF THE TAXONOMY OF PLEUROTHALLIS CROCODILICEPS (PLEUROTHALLIDINAE, ORCHIDACEAE) AND FOUR NEW SPECIES OF PLEUROTHALLIS IN SUBGENUS ANCIPITIA
}

\author{
Mark Wilson ${ }^{1,10}$, Katharine Dupree ${ }^{1}$, Wiel Driessen ${ }^{2}$, Bruno T. Larsen ${ }^{3}$, \\ Armin Löckher ${ }^{4}$, Andrea Niessen ${ }^{5}$, José Portilla $^{6}$, Marcos Salas Guerrero 7 , \\ Mario Andres Suarez ${ }^{8} \&$ Francisco Tobar-SuÁrez $^{9}$ \\ ${ }^{1}$ Department of Organismal Biology and Ecology, Colorado College, Colorado Springs, CO 80903, U.S.A. \\ ${ }^{2}$ Loosteeg 7, Panningen, The Netherlands. \\ ${ }^{3}$ Van Putlei 42, 2018 Antwerp, Belgium. \\ ${ }^{4}$ Naturhistorisches Museum Wien, Burgring 7, 1010 Vienna, Austria. \\ ${ }^{5}$ Orquídeas del Valle, Calle 10N \#9-31, Cali, Valle del Cauca, Colombia. \\ ${ }^{6}$ Ecuagenera, Km. 2 1/1 Vía a Cuenca Sector Llampasay, Gualaceo, Ecuador. \\ ${ }^{7}$ Nature and Culture International, Chachapoyas, Peru. \\ ${ }^{8}$ Manzana C, casa 77 B, Barrio Santa Mónica, Nariño, Colombia. \\ ${ }^{9}$ Arupos, E2 y Av. Yaloman, Quito, Ecuador. \\ ${ }^{10}$ Author for correspondence: email: mwilson@coloradocollege.edu
}

\begin{abstract}
In this paper we summarize the taxonomic history of Pleurothallis crocodiliceps Rchb.f. and demonstrate that the species described by Reichenbach did not possess the stereotypical minute, pubescent, tri-lobed lip, with basal lobes modified into "horns". The first two species described with such a lip were $P$. arietina and $P$. nelsonii. Rather than a single widely distributed, variable species, with a morphologically constant lip, P. crocodiliceps, we recognize the P. arietina-P. nelsonii species complex. Herein we describe four new species in this complex and discuss the morphological characters useful in distinguishing among the members of the complex. We also discuss the nature of the lip possessed by members of this complex and propose that it may mimic a female insect luring a male fly into pollinating the flower by pseudocopulation.

KEY wORDs: Ancipitia, Pleurothallis, Pleurothallidinae, pollination, pseudocopulation, SEM
\end{abstract}

Introduction. Pleurothallis crocodiliceps Rchb.f. was described by Reichenbach (1885) from a plant collected by Hermann Wagener in Agua de la Virgen, Province of Ocaña, Department of Norte de Santander, Colombia. The type material of $P$. crocodiliceps (Fig. 1) was transferred to the Herbarium of the Natural History Museum of Vienna (W) after Reichenbach's death. The subsequent taxonomic history of this and two related Central American species is pertinent because, prior to our study, new species of Pleurothallis with characteristics like those of the species described herein would have been classified as P. crocodiliceps.

At some time prior to 1923, Oakes Ames traced the type material of $P$. crocodiliceps (and Reichenbach's drawing from the holotype at W; Fig. 1) and the tracing was deposited in The Harvard University Herbarium (AMES 00074190; Fig. 2). Having seen the $P$. crocodiliceps holotype, Ames (1923) described two new Central American species: P. nelsonii Ames, from the State of Chiapas, Mexico; and P. arietina Ames, from the Province of Cartago, Costa Rica (Fig. 3). He described $P$. arietina as a "near ally" of $P$. crocodiliceps, but importantly, did not comment on any similarities or differences in labellar morphology. In 1946, M.B. Foster \& R. Foster collected a plant of Pleurothallis (collection \#1764; AMES 00395357) from a location between Convención and Carmen, Norte de Santander, Colombia, approximately 5-10 miles from Agua de la Virgen, the type locality for P. crocodiliceps. Ernesto Foldats drew this plant and appended the drawing above Garay's tracing of the $P$. crocodiliceps holotype on the herbarium sheet AMES 00074190, assuming them to be the same species (Fig. 2) (G. Romero, pers. comm.). Importantly, the species collected by 


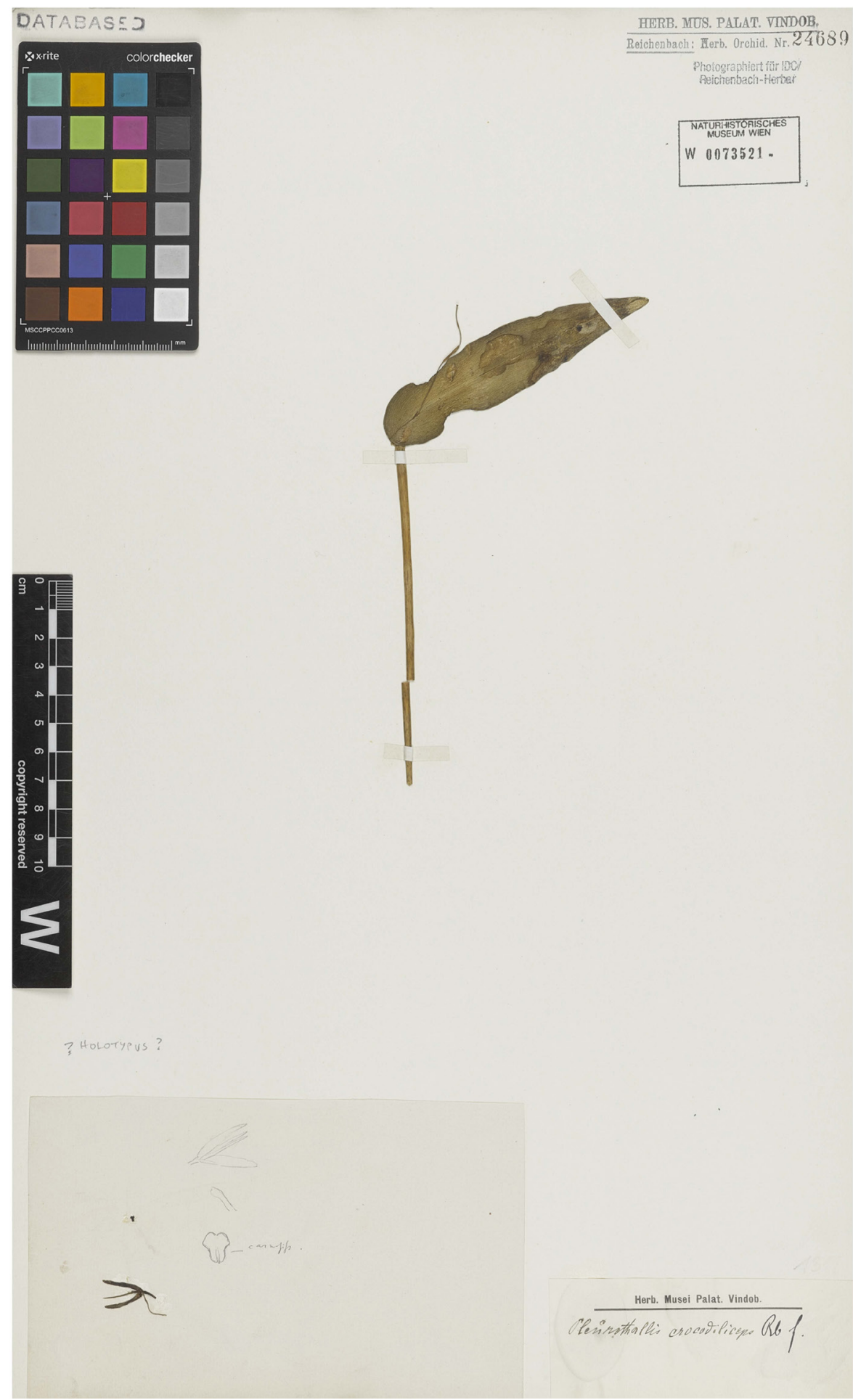

FIgURE 1. Pleurothallis crocodiliceps Rchb.f. holotype based on collection by Wagener from Agua de la Virgen, Norte de Santander, Colombia. (Courtesy of the Herbarium of the Natural History Museum of Vienna.) 


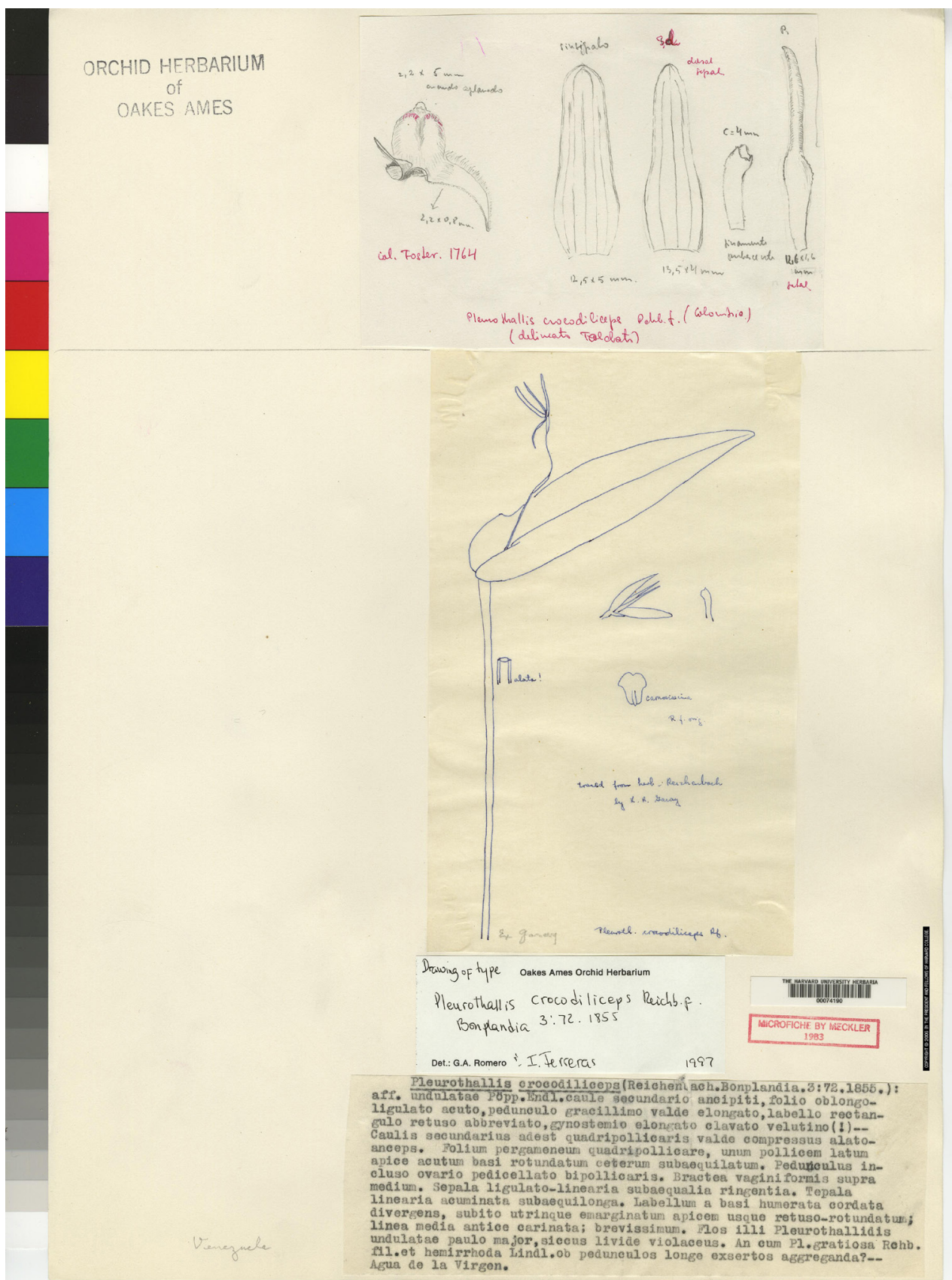

FIGURE 2. Pleurothallis crocodiliceps herbarium sheet from the Harvard University Herbarium (AMES 00074190). Above, drawing of Pleurothallis sp. collection by M.B. Foster \& R. Foster (collection \#1764; AMES 00395357), by Foldats. Below, tracing of $P$. crocodiliceps type material and Reichenbach's drawing of the flower parts, by Garay. (Courtesy of Harvard University Herbarium.)

the Fosters and drawn by Foldats is illustrated with a labellum or "lip" that is minute, pubescent and tri-lobed, with the two basal lobes forming forward- pointing "horns" (Fig. 2). The genesis of the idea that $P$. crocodiliceps Rchb.f. has such a lip, therefore, can be attributed to the assumption of Foldats that $P$. 


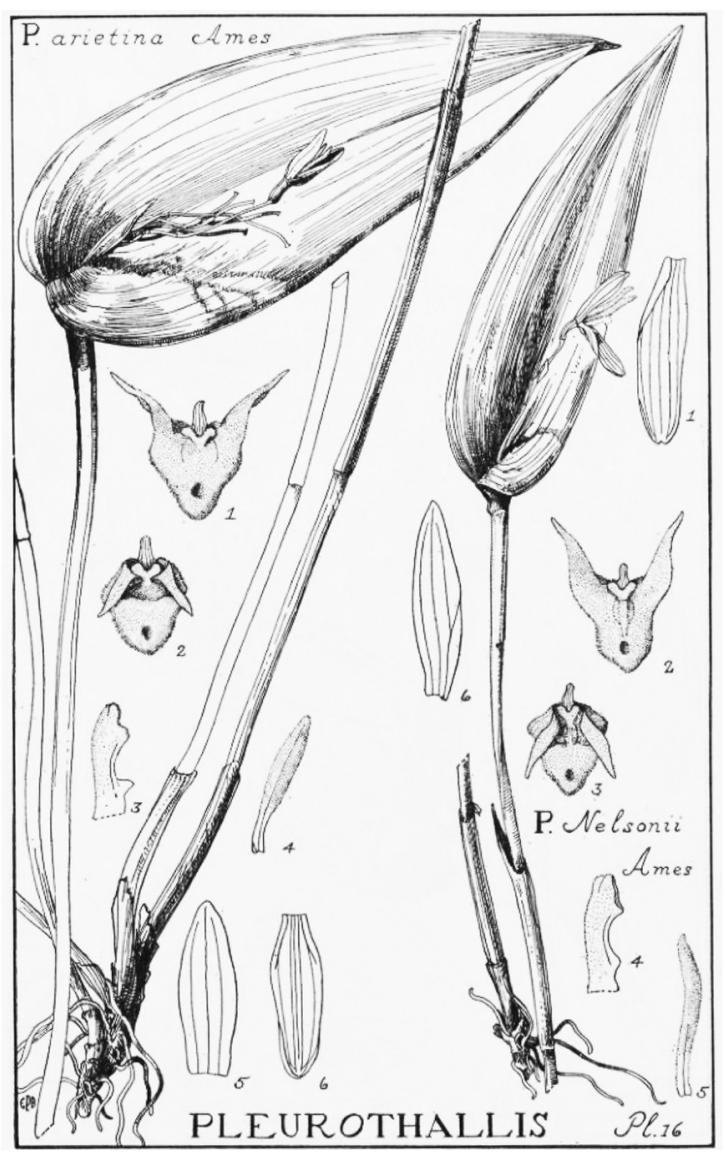

FiguRE 3. Drawings of Pleurothallis arietina and Pleurothallis nelsonii (Ames 1923).

crocodiliceps, as represented by Garay's tracing of the type (Fig. 2), was the same species as that collected by the Fosters (AMES 00395357). Foldats (1970) perpetuated this error when he described (but did not illustrate) a Venezuelan example of what he presumed to be $P$. crocodiliceps, along with a clear description of the tri-lobed lip, in Flora de Venezuela.

Luer (1975a) then described and illustrated $P$. crocodiliceps in "Pleurothallis of Ecuador" (Fig. 4c) using a plant resembling the drawing by Foldats on the herbarium sheet at Harvard (Fig. 2). Luer did not, however, examine the holotype in Vienna (Luer, pers. comm.). The error was continued by Dunsterville $(1979,1986)$ when he described and illustrated plants of $P$. crocodiliceps from Venezuela. And, finally, Luer (1989) cemented the idea of the stereotypical lip of $P$. crocodiliceps in his description and illustration in Icones Pleurothallidinarum VI
(Fig. 4d). However, the idea that $P$. crocodiliceps Rchb.f possessed a minute, pubescent, tri-lobed lip, with the two basal lobes forming forward-pointing "horns" is all based on the false assumption by Foldats that the plant collected by Wagener and described by Reichenbach was the same as the plant collected by the Fosters.

Reichenbach (1885) described the labellum of P. crocodiliceps "Labellum a basi humerata cordata divergens, subito utrinque emarginatum apicem usque retuso-rotundatum, linea media antice carinata; brevissimum". Neither this description, nor the drawing of the lip on the holotype (Fig. 1), nor the preserved lip attached to the holotype (Fig. 1 and 5b), match the lip of the plant drawn by Foldats and appended to the herbarium sheet with Garay's tracing of the $P$. crocodiliceps holotype (Fig. 2). Nor do they match the drawings of the lips of species purported to be $P$. crocodiliceps by Foldats (1970), Luer (1975a, 1989), or Dunsterville $(1979,1986)$. In other words, the species illustrated individually by Foldats, Luer, and Dunsterville are not $P$. crocodiliceps Rchb.f. and our concept of the stereotypical "crocodiliceps" lip is apparently based upon a decades-old mistake by Foldats.

This leaves the status of the Central American species P. arietina (Figs. 3 and 4a) and P. nelsonii (Figs. $3,4 \mathrm{~b}$ and 6 ) in an equivocal position. Luer has vacillated on the relationship between these two taxa and $P$. crocodiliceps: Luer (1975a) considered P. nelsonii and $P$. arietina to be synonyms of $P$. crocodiliceps; but Luer (1977), under Addenda et Corrigenda, stated "Selbyana 1: 67 Remove Pleurothallis arietina and P. nelsonii from the synonymy of $\mathrm{P}$. crocodiliceps" and he goes on to describe the distinguishing characteristics of $P$. arietina in the same publication. Then, reversing that position again, Luer (1989) listed the three epithets as synonyms. Following this lead, the World Checklist of Selected Plant Families (WCSP 2017) currently lists $P$. arietina, $P$. nelsonii and a third species, the Guatemalan P. microchila L.O.Williams, as heterotypic synonyms of $P$. crocodiliceps. However, given the new information regarding the nature of the lip of $P$. crocodiliceps, it is clear that $P$. arietina, P. microchila and P. nelsonii cannot be synonyms of P. crocodiliceps, since each possesses the minute, pubescent, tri-lobed, horned lip, which $P$. crocodiliceps does not (Fig. 5b). 

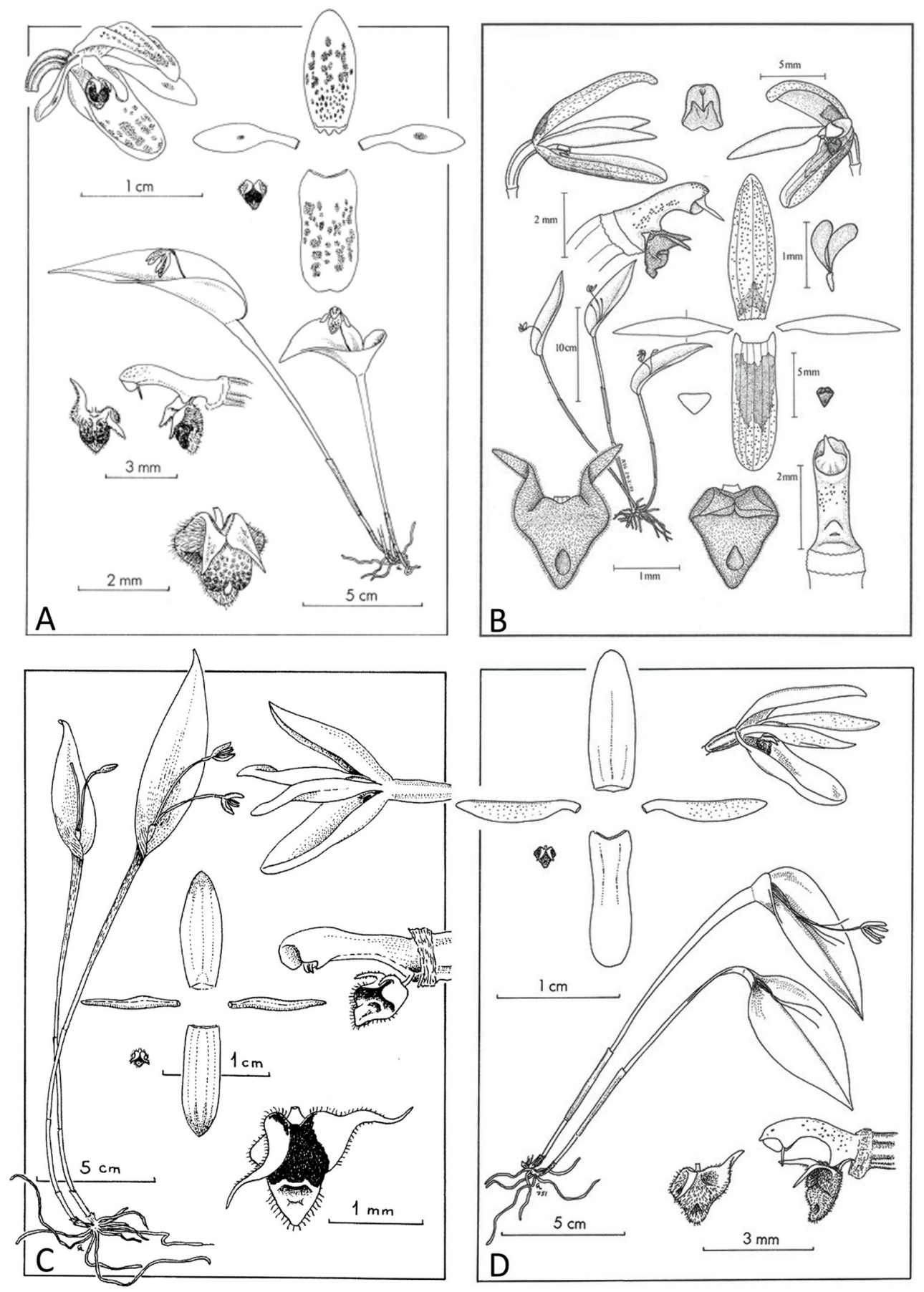

Figure 4. Drawings: A. Pleurothallis arietina (from Luer 1976, courtesy of Marie Selby Botanical Gardens); B. P. nelsonii (from Soto Arenas \& Solano 2003, courtesy of Solano Gómez); C. Pleurothallis sp. (labeled as P. crocodiliceps) from an Ecuadorian specimen collected by Dodson (Luer 1975a, courtesy of Marie Selby Botanical Gardens); and D. Pleurothallis sp. (labeled as P. crocodiliceps) from a Panamanian specimen (collection Luer \#0751) (Luer 1989, courtesy of Missouri Botanical Garden Press). 


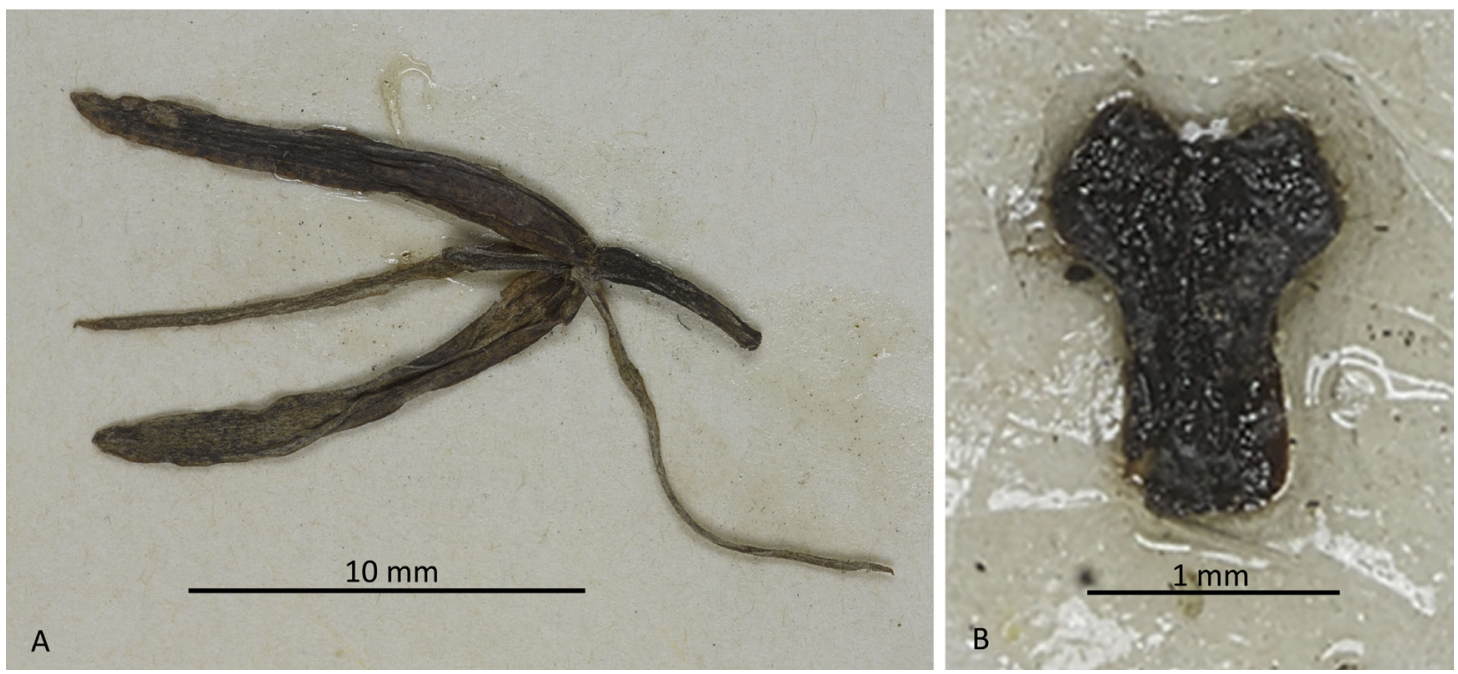

FIGURE 5. Details from scan of Pleurothallis crocodiliceps Rchb.f. holotype: A. whole flower; B. lip glued to herbarium sheet. (Courtesy of the Herbarium of the Natural History Museum of Vienna.)

To date, the prevailing opinion has been that $P$. crocodiliceps is a very variable, widely distributed species, occurring from southern Mexico through Central America and into the Andean countries of Venezuela, Colombia, Ecuador, Peru and Bolivia. At least until the publication of Ancipitia renieana Luer \& Sijm (Luer 2011), all species with a minute, pubescent, tri-lobed, horned lip have been considered to be variants of $P$. crocodiliceps. Knowing now that $P$. crocodiliceps has been mischaracterized, we suggest referring to this group of morphologically similar species with a minute, pubescent, tri-lobed, horned lip

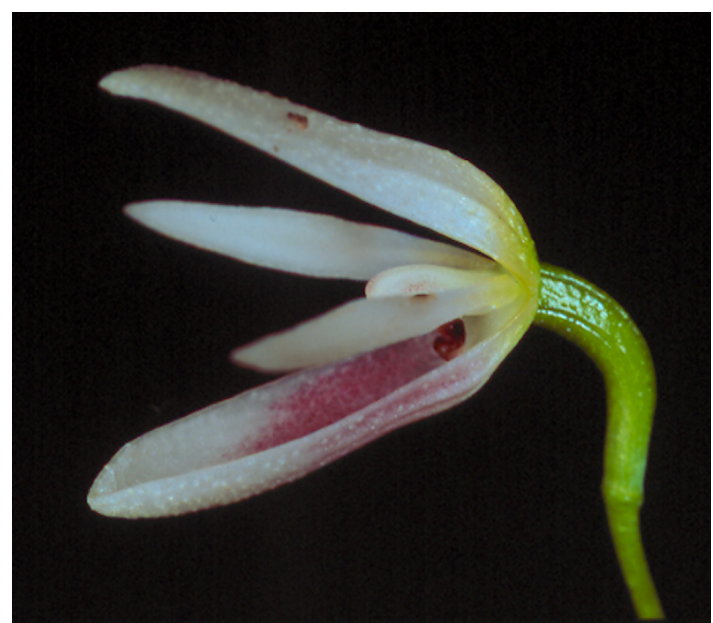

Figure 6. Photo of whole flower of Pleurothallis nelsonii (courtesy of Solano Gómez). as the "P. arietina-P. nelsonii species complex". We employ both epithets since those were the first two species described with the characteristic lip and since they were described simultaneously (Ames 1923). This species complex would include: P. arietina, $P$. microchila, P. onagriceps Luer \& Hirtz, P. nelsonii, and $P$. renieana (Luer \& Sijm) J.M.H.Shaw. Herein we describe four additional species of Pleurothallis attributable to the $P$. arietina- $P$. nelsonii species complex.

First, however, we must explain the choice of the genus Pleurothallis R.Br. over Ancipitia (Luer) Luer, as proposed by Luer (2004). Luer (1986) created subgenus Ancipitia for the group including $P$. crocodiliceps in his reorganization of the genus. The molecular phylogenetic study of the Pleurothallidinae by Pridgeon, Solano and Chase (2001) included only two species from subgenus Ancipitia, P. viduata Luer and $P$. niveoglobula Luer. In their nrDNA ITS tree, $P$. viduata and $P$. niveoglobula clustered in a strongly supported clade with the type of genus Pleurothallis, Pleurothallis ruscifolia (Jacq.) R.Br. Consequently, in their phylogenetic reorganization of the Pleurothallidinae, Pridgeon and Chase (2001) included subgenus Ancipitia in Pleurothallis. And, Pridgeon, Cribb, Chase and Rasmussen (2005) retained subgenus Ancipitia in their circumscription of genus Pleurothallis. The ongoing phylogenetic studies of genus Pleurothallis by Wilson et al. (2011, 2013) 
and Wilson (unpubl. data), incorporating a much more extensive sampling of species from this subgenus, support the retention of Ancipitia within Pleurothallis. In other words, at this time, the available molecular evidence does not support the recognition of genus Ancipitia proposed by Luer (2004) and, therefore, we describe the new species in Pleurothallis subgenus Ancipitia.

In this paper we describe four new species of Pleurothallis attributable to the $P$. arietina- $P$. nelsonii complex. And we present micro-morphological data obtained from scanning electron microscopy (SEM) of the labellum and discuss these in relation to taxonomy of the $P$. arietina-P. nelsonii complex and reproductive ecology of this group of species.

\section{Materials and Methods}

Morphological comparisons-. Living material of these species was examined by the first author on site in the collections of Ecuagenera (Gualaceo, Ecuador), Equaflor-A (Cuenca, Ecuador) and Orquídeas del Valle (Cali, Colombia). Plants were also imported into U.S.A from Ecuagenera, Equaflor-A and Orquídeas del Valle and grown in the collection of Wilson at Colorado College for more extensive examination. These materials were used for creation of the Lankester composite digital plates (LCDPs) and for morphological and taxonomic comparisons. Photographs were taken with a Canon EOS 40D using a Canon $100 \mathrm{~mm}$ f 2.8 macro-lens and extension tubes as required. In order to determine novelty, these species were compared to the types of $P$. crocodiliceps Rchb.f. (holotype: W!), P. arietina Ames (holotype: AMES!) and $P$. nelsonii Ames (holotype: AMES!); to a database of species descriptions, photographs and scans of types amassed by the first author over a 10 -year period; and to all pertinent literature, including but not limited to: Bennet and Christenson (1993), Dodson (2003); Dodson and Dodson (1980, 1982, 1989), Escobar (1994, 2006), Luer (1975a, 1975b, 1975c, 1976, 1977, 1986, 1989, 2004, 2009, 2011), Luer and Thoerle (2013), Schweinfurth $(1959,1970)$ and Zelenko and Bermudez (2009).

Collections in Ecuador and Peru-. Plants in the living collection at Ecuagenera were collected as part of the project "Rescate, conservación, reproducción y manejo ex-situ de la flora del Ecuador", Ministerio del Ambiente authorization No 004-2016-IC-FLODNB/MA. Material of P. manningiana was collected under a permit \# N 292-2016-SERFOR/DGGSPFFS granted to Marcos Salas Guerrero by the Servicio Nacional Forestal y de Fauna Silvestre (SERFOR), Peru.

Preparation of types-. Material from the collection of Ecuagenera (Gualaceo, Ecuador) was used to create herbarium specimens accessioned into the Universidad del Azuay (HA) herbarium. Material from plants imported into U.S.A. was used for the creation of herbarium specimens accessioned into the Colorado College (COCO) herbarium. Flowers were preserved in Kew Mix (5\% formalin [37.6\% formaldehyde], 53\% methanol, $5 \%$ glycerol, and $37 \%$ deionized water).

Scanning electron microscopy-. Fresh-harvested flowers were preserved in Kew Mix. For SEM flowers were dehydrated in successively higher concentrations of ethanol $(80 \%, 95 \%, 100 \%, 100 \%)$ for $15 \mathrm{~min}$ each before being placed in freshly-opened $100 \%$ ethanol. Specimens were dehydrated in a critical point dryer (EMS 850) prior to mounting and sputter coating. Specimens were imaged using a Jeol JSM-6390LV scanning electron microscope with an accelerating voltage of $10-15 \mathrm{kV}$.

\section{Results}

Morphological comparisons - labellum-. The labella or "lips" of the Pleurothallis species were examined by light microscopy, macro-photography and SEM. The lips of the first three species, P. wielii, $P$. andreae and $P$. manningiana, were superficially similar, consisting of a three-lobed structure, the central lobe modified with a front-central cavity and the two basal lobes modified into forward projecting "horns". In other words, the characteristic $P$. arietina-P. nelsonii species complex lip. However, upon closer examination the lips were observed to vary significantly in length and width; length and orientation of "horns"; length and distribution of hairs; presence or absence and prominence of glabrous calli; and the morphology of the cavity (Table 1; Figs. 7 and 8). The lip of the fourth species, P. kelsoi, though also three-lobed with a front-central 
TABLE 1. Comparison of dimensions of Pleurothallis wielii, P. andreae and P. manningiana.

\begin{tabular}{|c|c|c|c|}
\hline Species & P. wielii & P. andreae & P. manningiana \\
\hline Whole plant $(\mathrm{cm})$ & $\sim 22$ & $\sim 23$ & $\sim 27$ \\
\hline Ramicaul (cm) & $14-18.5$ & $11.5-15.4$ & $13.5-20.0$ \\
\hline Leaf $(\mathrm{cm})$ & $7.0-9.1 \times 3.0-4.5$ & $6.0-7.6 \times 2.2-2.7$ & $5.3-6.9 \times 2.0-2.8$ \\
\hline Dorsal sepal $(\mathrm{mm})$ & $13.0 \times 4.0$ & $12.0 \times 3.0$ & $12.5 \times 2.4$ \\
\hline Synsepal (mm) & $12.4 \times 3.8$ & $12.0 \times 2.75$ & $11.5 \times 2.7$ \\
\hline Petals (mm) & $12.0 \times 1.5$ & $11.0 \times 1.5$ & $12.0 \times 1.2$ \\
\hline Lip (mm) & $2.5 \times 2.0$ & $2.4 \times 1.8$ & $1.9 \times 1.4$ \\
\hline Column (mm) & $4.0 \times 0.68$ & $4.4 \times 0.71$ & $3.1 \times 0.64$ \\
\hline
\end{tabular}

cavity, was quite different in morphology, with a wider pandurate central lobe and basal lobes more like those of Pleurothallis caniceps Luer (Fig. 9). None of these species possessed a glenion as occurs on the labella of species in Pleurothallis subsection Macrophyllae-Fasciculatae (Wilson et al. 2016), or any other tissue type recognizable as secretory or potentially able to provide a pollinator reward.
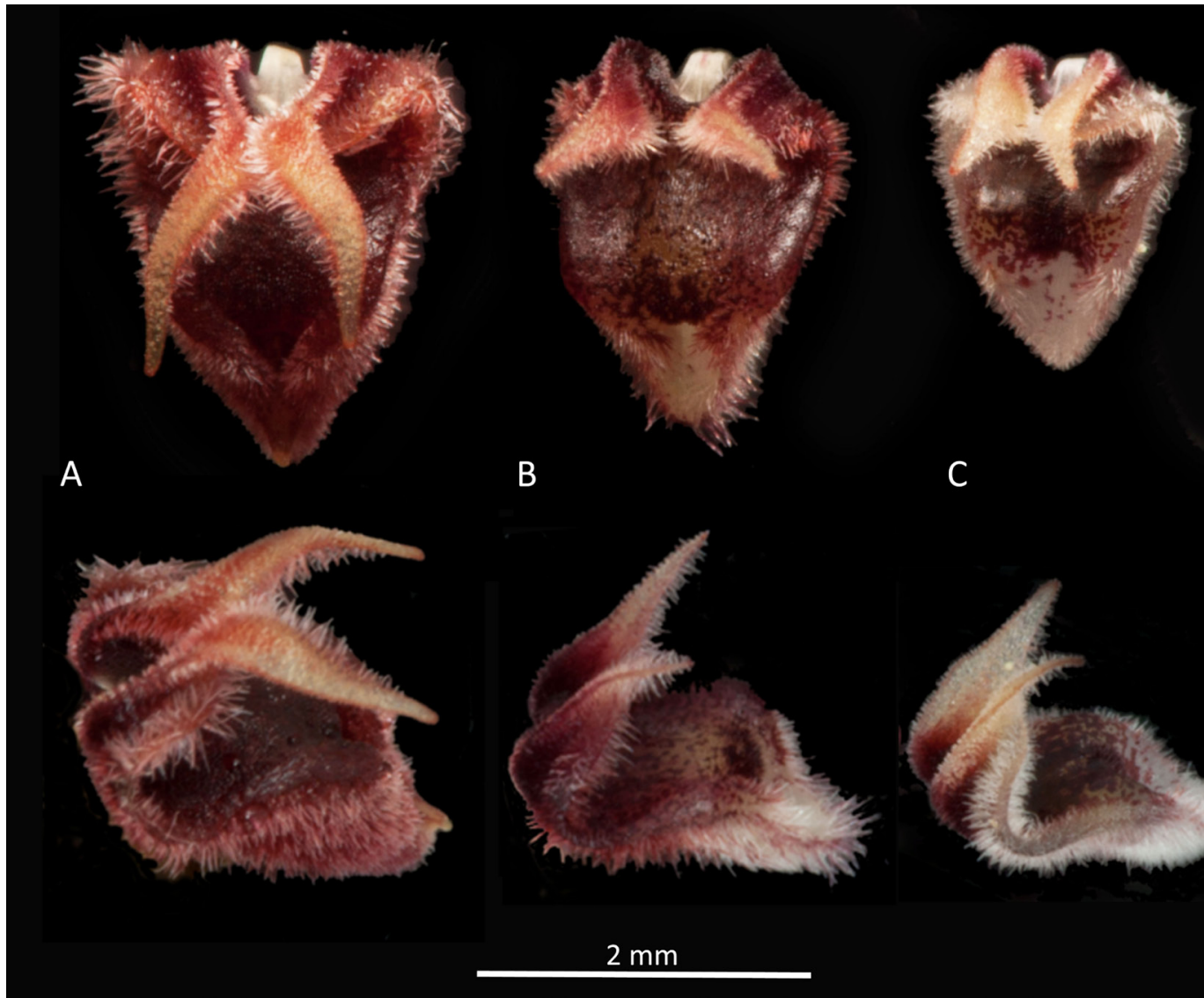

B

C

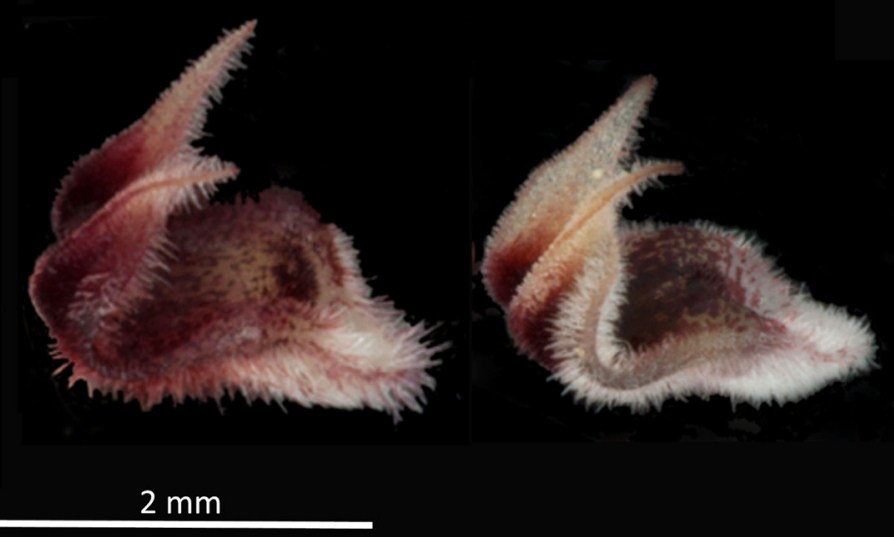

Figure 7. Comparison of lips - macro-photographs: A. Pleurothallis wielii (M.Wilson \& J.Portilla PL0929); B. P. andreae (from paratype M. Wilson \& J.Portilla PL0930); and C. P. manningiana (from paratype M. Wilson \& J.Portilla PL0931). Photos by Wilson. 

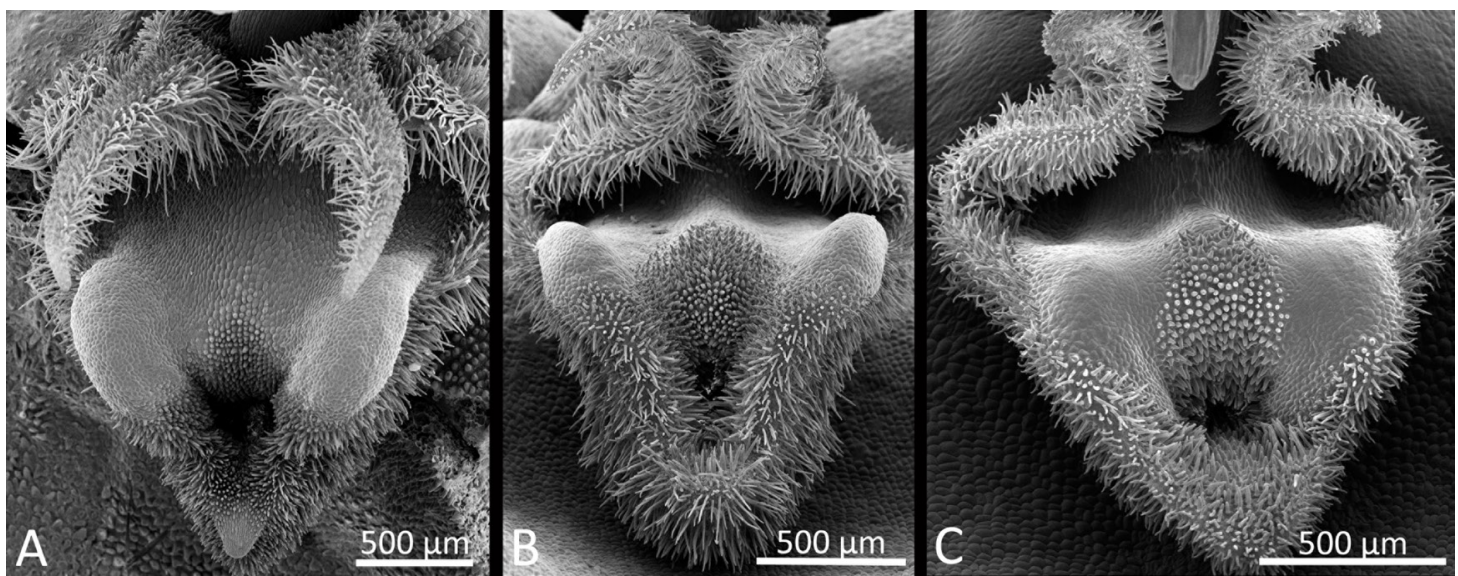

FiguRE 8. Comparison of lips - scanning electron micrographs: A. Pleurothallis wielii (from holotype M. Wilson \& J.Portilla PL0713); B. P. andreae (from paratype M.Wilson \& A.Niessen PL0962); and C. P. manningiana (from paratype M.Wilson \& J.Portilla PL0931). Scanning electron micrographs prepared by Dupree.

Morphological comparisons - gynostemium - . The gynostemium or "column" of the first three species, $P$. wielii, $P$. andreae and $P$. manningiana, were examined by light microscopy, macro-photography and SEM. The columns of these three species were superficially similar, being white, spotted with pink or rose, papillate over the entire length and having a tri-partite tip with a subapical anther. However, like the lips, the columns were found

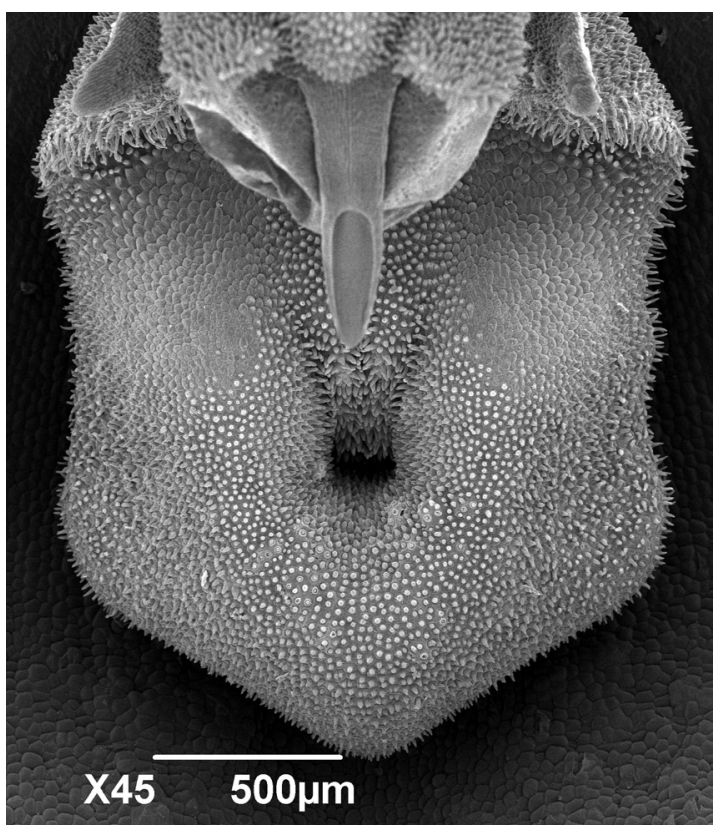

FIGURE 9. Scanning electron micrograph of lip of Pleurothallis kelsoi. Scanning electron micrograph prepared by Dupree from M.Wilson \& J.Portilla PL0594. to vary when scrutinized closely, exhibiting differences in length; orientation (i.e. more or less straight, or bent downwards in terminal third); and position of the modified column foot (i.e. close to the insertion of the lip on the column or more distant) (Table 1; Figs. 10 and 11).

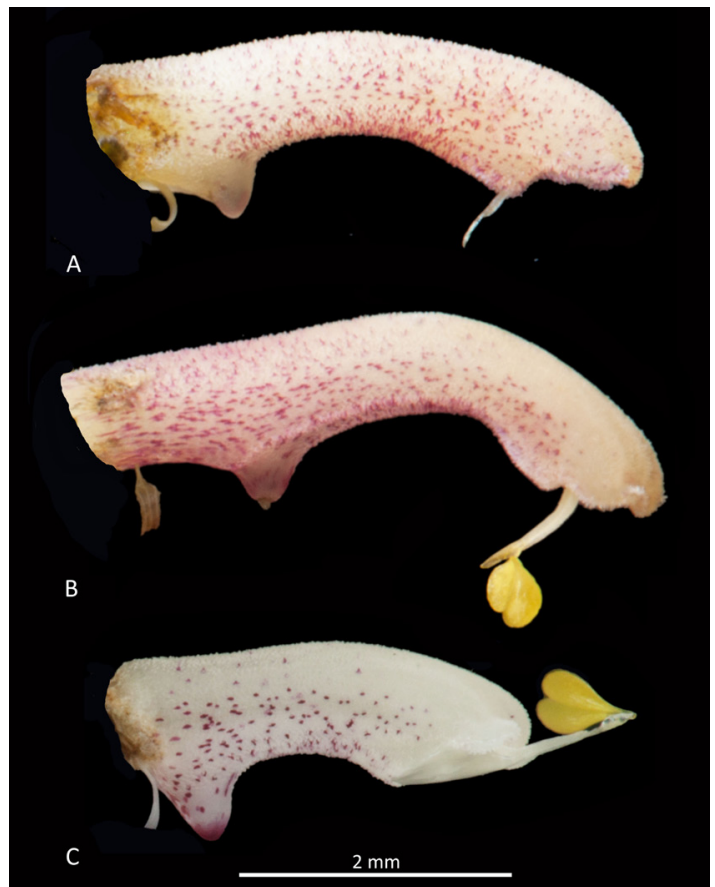

FIgURE 10. Comparison of columns - macro-photographs: A. Pleurothallis wielii (M.Wilson \& J.Portilla PL0929); B. P. andreae (from paratype M.Wilson \& J.Portilla PL0930); and C. P. manningiana (from paratype M. Wilson \& J.Portilla PL0931). Photos by Wilson.

LANKESTERIANA 17(2). 2017. (C) Universidad de Costa Rica, 2017. 


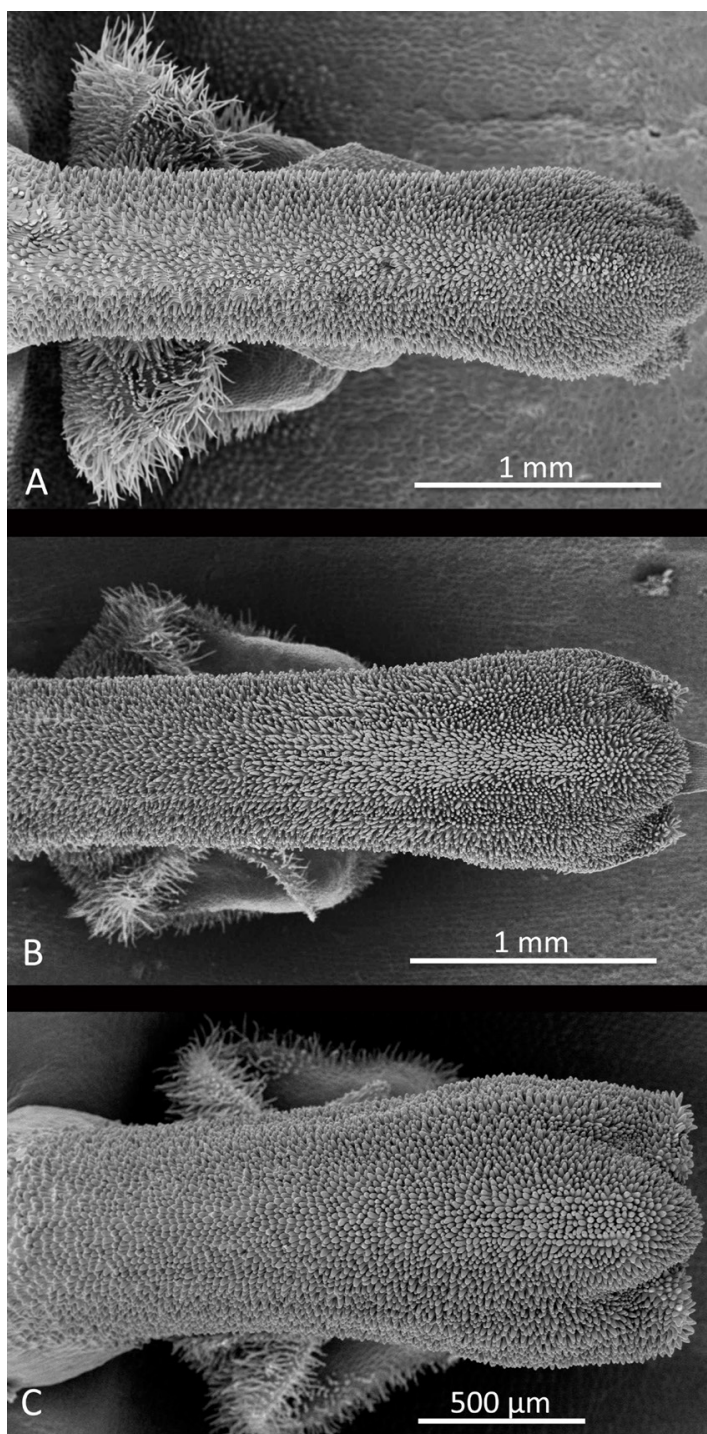

Figure 11. Comparison of columns - scanning electron micrographs: A. Pleurothallis wielii (from holotype M.Wilson \& J.Portilla PL0713); B. P. andreae (from paratype M.Wilson \& A.Niessen PL0962); and C. P. manningiana (from paratype M.Wilson \& J.Portilla PL0931). Scanning electron micrographs by Dupree.

\section{Taxonomic treatment}

Luer (1989) listed $P$. arietina and $P$. nelsonii as synonyms of $P$. crocodiliceps. And, the World Checklist of Selected Plant Families (WCSP 2017), currently lists those two species, plus $P$. microchila, as heterotypic synonyms of $P$. crocodiliceps. Based on the distinctive morphology of the lip in P. arietina,
P. nelsonii and P. microchila, that is not possessed by $P$. crocodiliceps, these three species can no longer be considered heterotypic synonyms of $P$. crocodiliceps. The three species, $P$. arietina, $P$. nelsonii and $P$. microchila, therefore, are removed from synonymy with $P$. crocodiliceps.

Pleurothallis arietina Ames Schedul. Orchid. 4: 16. 1923.

Pleurothallis nelsonii Ames Schedul. Orchid. 4: 22. 1923.

Pleurothallis microchila L.O.Williams Fieldiana, Bot. 31: 259. 1967.

Pleurothallis wielii Mark Wilson, B.T.Larsen \& J.Portilla, sp. nov. (Figs. 12-14)

TYPE: Ecuador. Purchased from Ecuagenera, without collection data, as Pleurothallis crocodiliceps $\mathrm{f}$. xanthina and flowered in cultivation at Colorado College, January 2016, M. Wilson \& J. Portilla PL0713 (holotype: COCO!).

$P$. wielii is similar to both $P$. arietina and $P$. nelsonii from which it differs in the color of the flowers (mustard yellow with different variable amounts of brown suffusing the sepals and petals in $P$. wielii vs. "Pinard yellow" in $P$. arietina and white suffused with rose in $P$. nelsonii); the degree of openness of the flowers or sepal angle (fully open or $\sim 150-170^{\circ}$ in $P$. wielii vs. partially open or $\sim 50-70^{\circ}$ in $P$. arietina and P. nelsonii); the presentation or aspect of the flowers (face down towards the leaf in $P$. wielii vs. more or less parallel to the leaf in $P$. arietina and $P$. nelsonii); the surface texture of the flowers (smooth in $P$. wielii vs. verrucose in $P$. arietina and $P$. nelsonii).

Plant medium, to $\sim 22 \mathrm{~cm}$ tall, epiphytic, caespitose. Roots slender, densely fasciculate. Ramicauls erect, slender, sharply ancipitous, 14.0-18.5 cm long, 3.7$5.0 \mathrm{~mm}$ wide below leaf, enclosed by central sheath $3.4-3.6 \mathrm{~cm}$ long, basal sheath $2.0-2.9 \mathrm{~cm}$ long. Leaves erect to suberect, ovate, acute, cuneate, 6.7-9.1 $\times$ $3.0-4.5 \mathrm{~cm}$, sessile, entire, coriaceous. Inflorescence fascicle of solitary, successive flowers, borne from reclining spathaceous bract at base of leaf $7 \mathrm{~mm}$ long; pedicel 4.3-5.9 cm long; floral bract $7 \mathrm{~mm}$ long; ovary lightly rugose, $4.5 \mathrm{~mm}$ long. Dorsal sepal mustard 


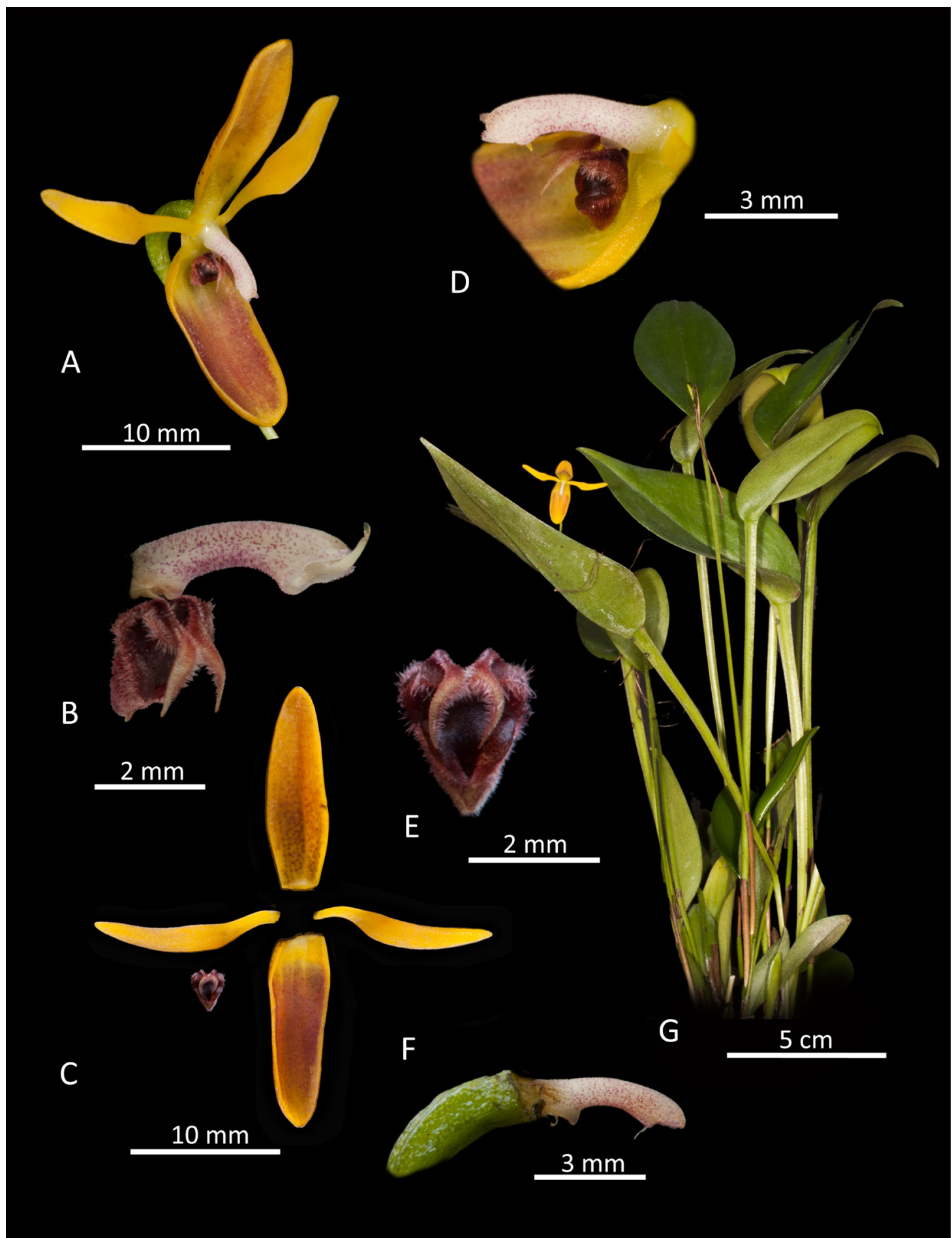

FIgURE 12. Lankester composite digital plate of Pleurothallis wielii: A. whole flower (3/4 view); B. column and lip (side view); C. floral dissection; D. column, lip and base of synsepal (3/4 view); E. lip (top view); F. column and ovary; and G. whole plant. LCDP prepared by Wilson from paratype M. Wilson \& J.Portilla PL0929. 


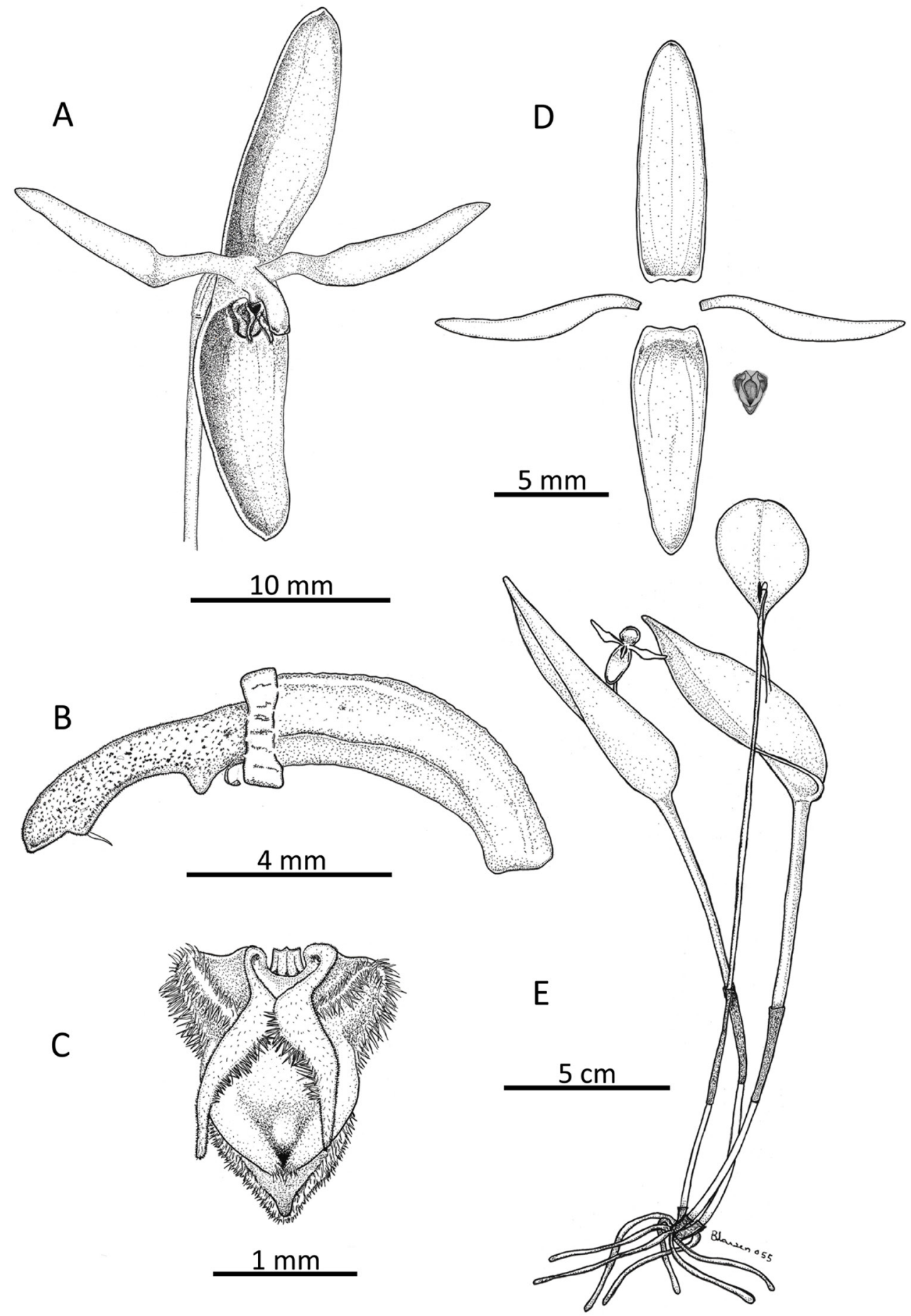

FiguRE 13. Drawing of Pleurothallis wielii: A. whole flower (3/4 view); B. column and ovary; C. lip (top view); D. floral dissection; and E. whole plant. Drawings prepared by Larsen from photos of holotype M.Wilson \& J.Portilla PL0713 and paratype M.Wilson \& J.Portilla PL0929. 


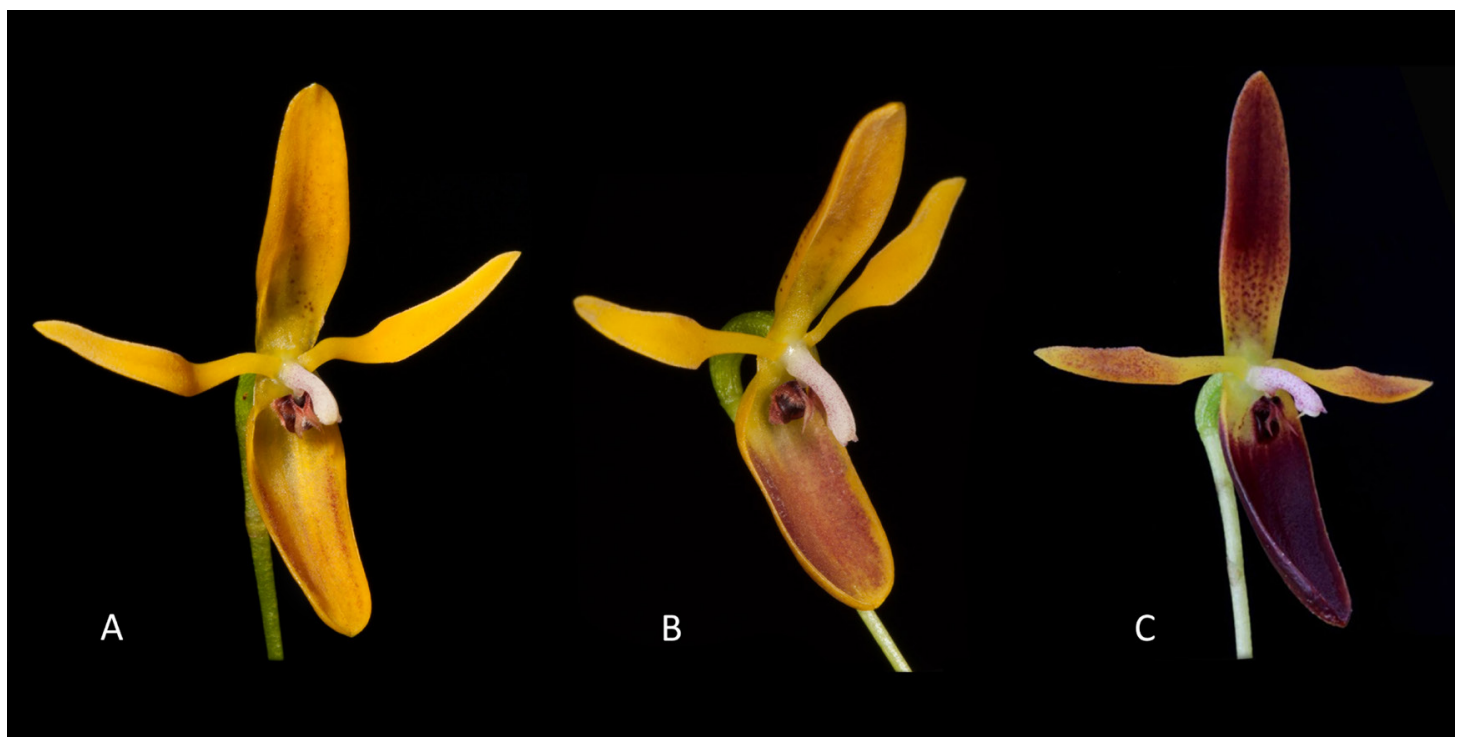

FIgURE 14. Color forms of Pleurothallis wielii: A. mustard yellow with light chestnut spotting (M. Wilson \& J.Portilla PL0713); B. mustard yellow with heavy chestnut spotting (M.Wilson \& J.Portilla PL0929); and C. mustard yellow background with heavy, dark chestnut suffusion (plant in Driessen collection). Photos by Wilson (A and B) and Driessen (C).

yellow lightly or heavily stippled with brown or heavily suffused with purple-brown fading toward base, ovatetriangular, subacute, concave, $13 \times 4 \mathrm{~mm}$, carinate, entire, glabrous, fleshy. Lateral sepals mustard yellow lightly or heavily stippled with brown or heavily suffused with purple-brown fading at base completely connate into ovate, concave synsepal, subacute, $12.4 \times$ $3.8 \mathrm{~mm}$, entire, glabrous, fleshy. Petals mustard yellow, linear-lanceolate, acute, obtusely angled in the lower margin, $12.0 \times 1.5 \mathrm{~mm}$, minutely pubescent, fleshy. Lip chestnut, $2.5 \times 2.0 \mathrm{~mm}$ unexpanded, attached to column by flexible strap, three-lobed, middle lobe chestnut, triangular, thick, densely pubescent, acute, adaxially glabrous centrally with a pair of elevated pulvinate calli from the base of the lateral lobes to below the cavity, apice rounded, cream stippled with chestnut, with conical callus below tip, basal lobes narrowly-triangular, densely long-pubescent on outer margin, erect, tips cream to pale brown, folded outwards, base elevated, subtruncate, hinged behind a conical callus above base of column. Column white, stippled with pink-red, terete, papillose, $4.5 \mathrm{~mm}$ long, anther apical, stigma ventral. Capsule not seen.

Additional material StUdied: Flowered in cultivation at Ecuagenera, Gualaceo, Ecuador, without collection data, November 2015, M. Wilson \& J. Portilla
PL0929 (paratype: COCO!). P. crocodiliceps Rchb.f. (holotype: W!); P. arietina Ames (holotype: AMES!); P. nelsonii Ames (holotype: AMES!); and P. microchila (holotype: F!).

Etymology: Named to honor Wiel Driessen of The Netherlands, enthusiastic orchid hobbyist with expertise in the species of subgenus Ancipitia and cultivator of this species. The name Pleurothallis driessenii Luer, based on the family name has been described previously, so the given name was employed.

Distribution AND HABITAT: While this species was observed for the first time in cultivation at Ecuagenera by the first author, plants of the same species cultivated in The Netherlands are believed to have been collected in Peru many years ago. Geographic distribution and habitat data for this species will be sought in the future.

Pleurothallis andreae Mark Wilson, B.T.Larsen \& J.Portilla, sp. nov. (Figs. 15-16)

TYPE: Colombia. Purchased from Orquídeas del Valle, Cali, Colombia, without collection data, as Pleurothallis viduata Luer and flowered in cultivation at Colorado College, February 2016, M. Wilson \& A. Niessen PL0962 (holotype: COCO!).

Pleurothallis andreae is similar to both P. arietina 


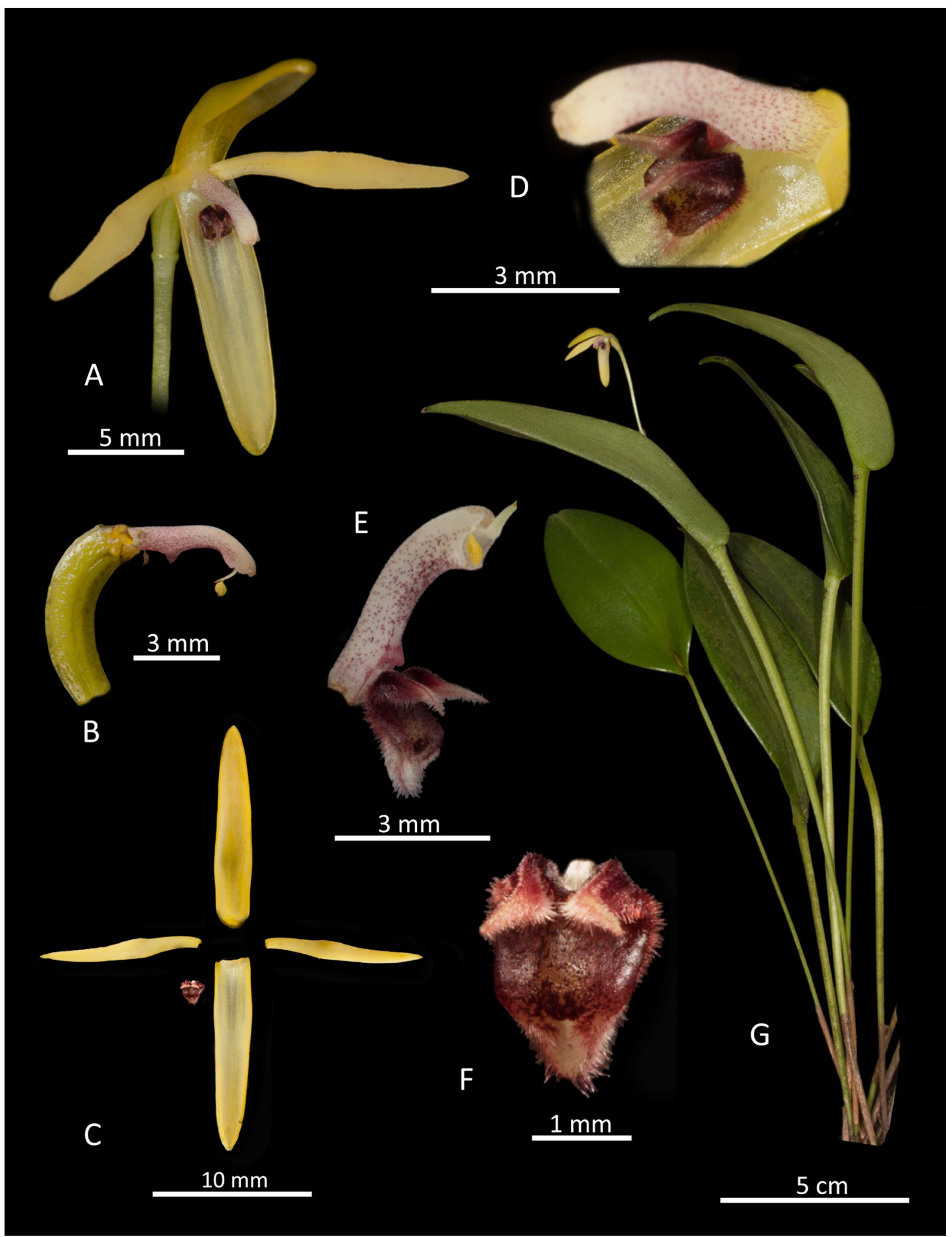

FIgURE 15. Lankester composite digital plate of Pleurothallis andreae: A. whole flower (3/4 view); B. column and ovary; C. floral dissection; D. column, lip and base of synsepal (3/4 view); E. column and lip (side view); F. lip (top view); and G. whole plant. LCDP prepared by Wilson from paratype M. Wilson \& J.Portilla PL0930. 


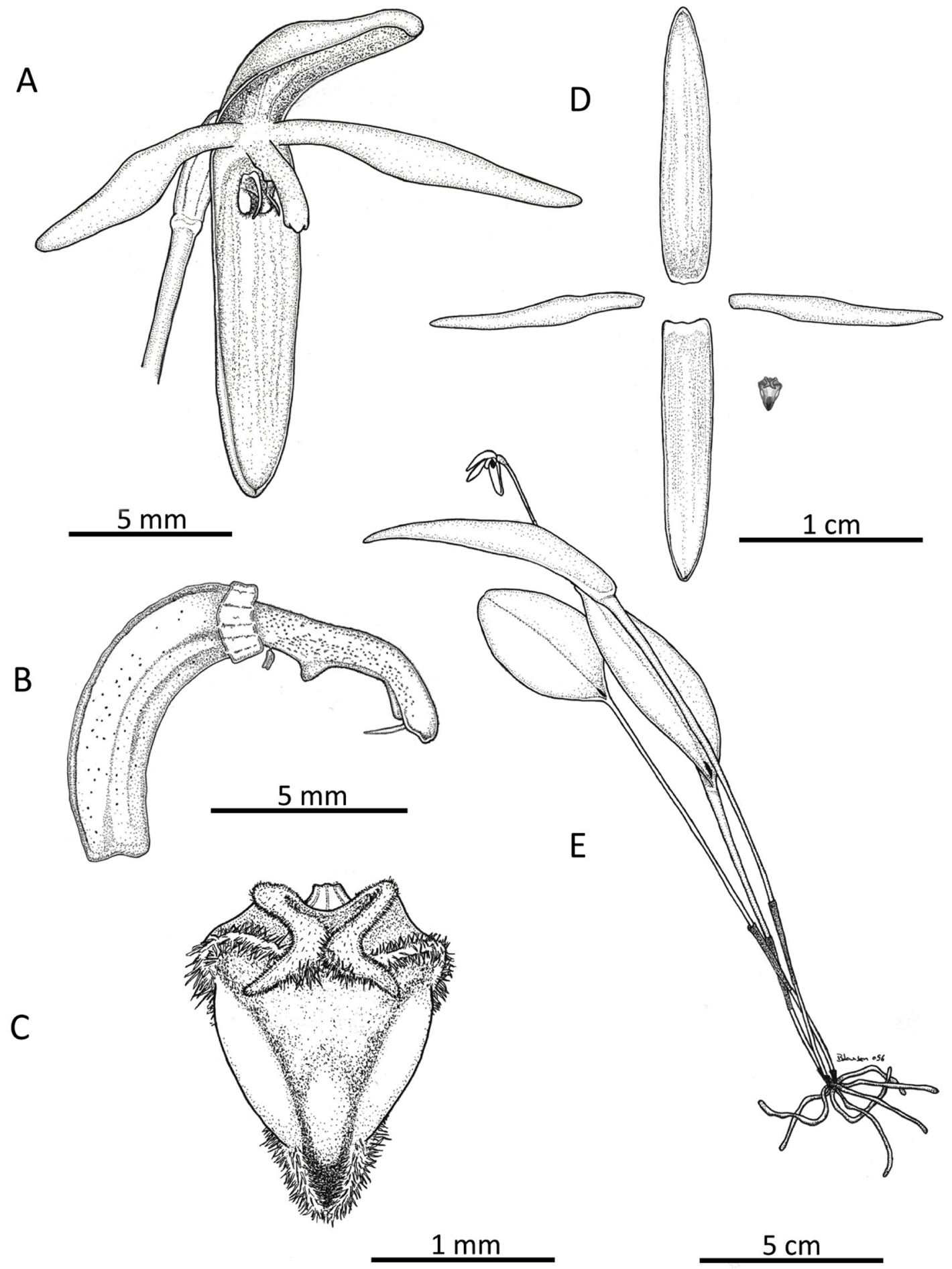

Figure 16. Drawing of Pleurothallis andreae: A. whole flower (3/4 view); B. column and ovary; C. lip (top view); D. floral dissection; and E. whole plant. Drawing prepared by Larsen from photos of paratype M. Wilson \& J.Portilla PL0930. 
and $P$. nelsonii from which it differs in the color of the flowers (pale lemon yellow in $P$. andreae vs. "Pinard yellow" in $P$. arietina and white suffused with rose in P. nelsonii); the degree of openness of the flowers or sepal angle (wide open or $\sim 110-130^{\circ}$ in $P$. andreae vs. partially open or $\sim 50-70^{\circ}$ in $P$. arietina and $P$. nelsonii); the surface texture of the flowers (smooth in $P$. andreae vs. verrucose in P. arietina and P. nelsonii).

Plant medium, to $\sim 23 \mathrm{~cm}$ tall, epiphytic, caespitose. Roots slender, densely fasciculate. Ramicauls 11.5-15.4 $\mathrm{cm}$ long, 2.5-3.0 mm wide below leaf, erect, slender, sharply ancipitous, enclosed by papery basal sheath. Leaves erect to suberect, ovate, acute, cuneate, 6.0-7.6 $\times 2.2-2.7 \mathrm{~cm}$, sessile, entire, coriaceous. Inflorescence fascicle of solitary, successive flowers, borne from reclining spathaceous bract at base of leaf, ovary smooth to lightly verrucose, $7 \mathrm{~mm}$ long. Dorsal sepal pale to darker lemon-yellow, ovate-triangular, acute, concave, $12 \times 3 \mathrm{~mm}$, entire, glabrous, three-veined, fleshy. Lateral sepals pale to darker lemon-yellow, completely connate into an transversely-ovate concave synsepal, acute, $12.0 \times 2.75 \mathrm{~mm}$, entire, glabrous, five-veined. Petals pale to darker lemon-yellow, subulate, acute, $11.0 \times 1.5 \mathrm{~mm}$, entire, glabrous, one-veined, fleshy. Lip chestnut brown, central lobe with white tip, lateral lobes with pale chestnut brown tips, three-lobed, $2.2 \times 1.6 \mathrm{~mm}$ (unexpanded), attached to the column by a flexible strap, the middle lobe triangular, thick, densely pubescent, acute, glabrous adaxially with a pair of longitudinal calli from just above the base of the basal lobes to just below the apice, cavity below the sulcate, densely pubescent, rounded apice, the basal lobes narrowly-triangular, densely pubescent on the outer margin, erect, the tips folded outwards, the base elevated, subtruncate, hinged behind a conical callus above the base of the column. Column white, stippled with pink-red, terete, densely papillose, $4.7 \mathrm{~mm}$ long, the anther and stigma subapical. Capsule unknown.

Additional material studied: Funes, Nariño, Colombia, February 2017, M. A. Suarez 4016 (paratype: PSO!). Flowered in cultivation at Orquídeas del Valle, Cali, Colombia, without collection data July 2017, M. Wilson \& A. Niessen PL0986 (paratype: CUVC!). Flowered in cultivation at Ecuagenera, Gualaceo, Ecuador, November 2015, M. Wilson \& J. Portilla PL0930 (paratype: COCO!). P. crocodiliceps
Rchb.f. (holotype: W!); P. arietina Ames (holotype: AMES!); P. nelsonii Ames (holotype: AMES!); and $P$. microchila (holotype: F!).

Eтymology: Named to honor Andrea Niessen, owner of Orquídeas del Valle, Cali, Colombia, grower of this species, for contributions to ex situ conservation of Pleurothallidinae and other orchids of Valle del Cauca. The names Pleurothallis niesseniae Luer and P. paraniesseniae J.M.H.Shaw, based on the family name, have been described previously, so the given name was employed.

Distribution AND habitat: $P$. andreae has been observed and photographed in situ near El Triunfo, north of Baños, Province of Tungurahua, Ecuador on the western slope of the Cordillera de los Llanganates at $\sim 1900$ m by Alberto Guerrero (Guerrero pers. comm.). P. andreae has also been observed and collected approximately 170 miles away in situ near Funes, southwest of Pasto, Department of Nariño, Colombia on the western slope of the Cordillera Central at $2800-2980 \mathrm{~m}$ by Mario Andres Suárez.

Conservation status: $P$. andreae is relatively secure in situ due to the fairly wide distribution from central Ecuador to southern Colombia, though future deforestation or habitat alteration due to climate change could reverse that situation. Its presence in commercial collections in Ecuador (Ecuagenera) and Colombia (Orquídeas del Valle) as well as private collections in North America ensure its ex situ conservation.

Pleurothallis manningiana Mark Wilson, Salas Guerr. \& B.T.Larsen, sp. nov. (Figs. 17-20).

TYPE: Ecuador. Flowered in cultivation at Ecuagenera Orchid Nursery, Gualaceo, Ecuador, without collection data, November 2015, M. Wilson \& J. Portilla PL0931 (holotype: HA!).

Pleurothallis manningiana is similar to both $P$. arietina and $P$. nelsonii from which it differs in the color of the sepals (cream colored or sometimes pale yellow with three brown stripes and occasionally brown spots vs. "Pinard yellow" in P. arietina and white suffused with rose in $P$. nelsonii); the color of the petals (cream colored or sometimes pale yellow suffused at the base with brown vs. "Pinard yellow" 


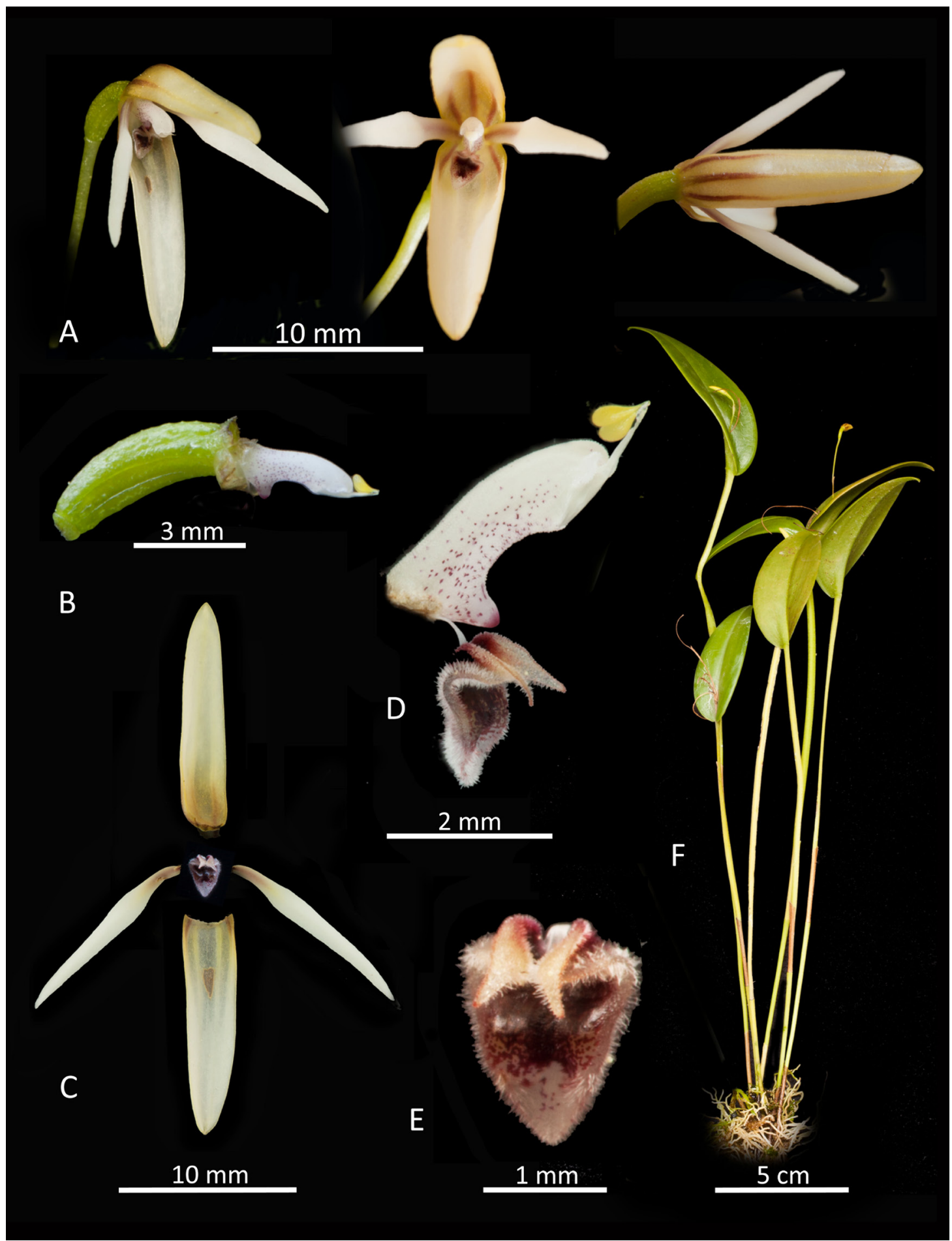

FIgURE 17. Lankester composite digital plate of Pleurothallis manningiana: A. whole flower (3/4, front and top views); B. column and ovary; C. floral dissection; D. column and lip (side view); E. lip (top view); and F. whole plant. LCDP prepared by Wilson from paratype M.Wilson \& J.Portilla PL0931. 

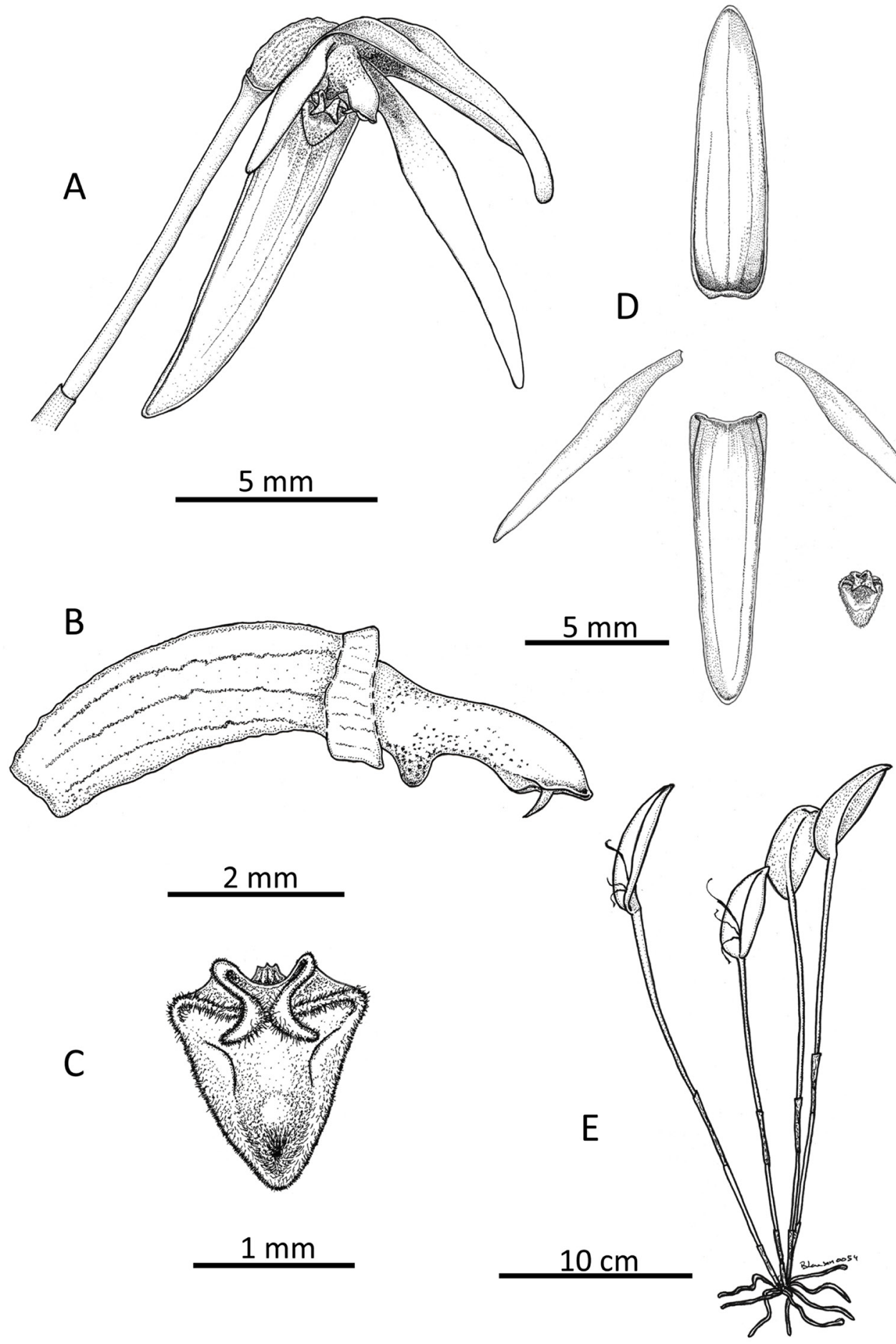

Figure 18. Drawing of Pleurothallis manningiana: A. whole flower (3/4 view); B. column and ovary; C. lip (top view); D. floral dissection; and E. whole plant. Drawing prepared by Larsen from photos of paratype M. Wilson \& J.Portilla PL0931. 

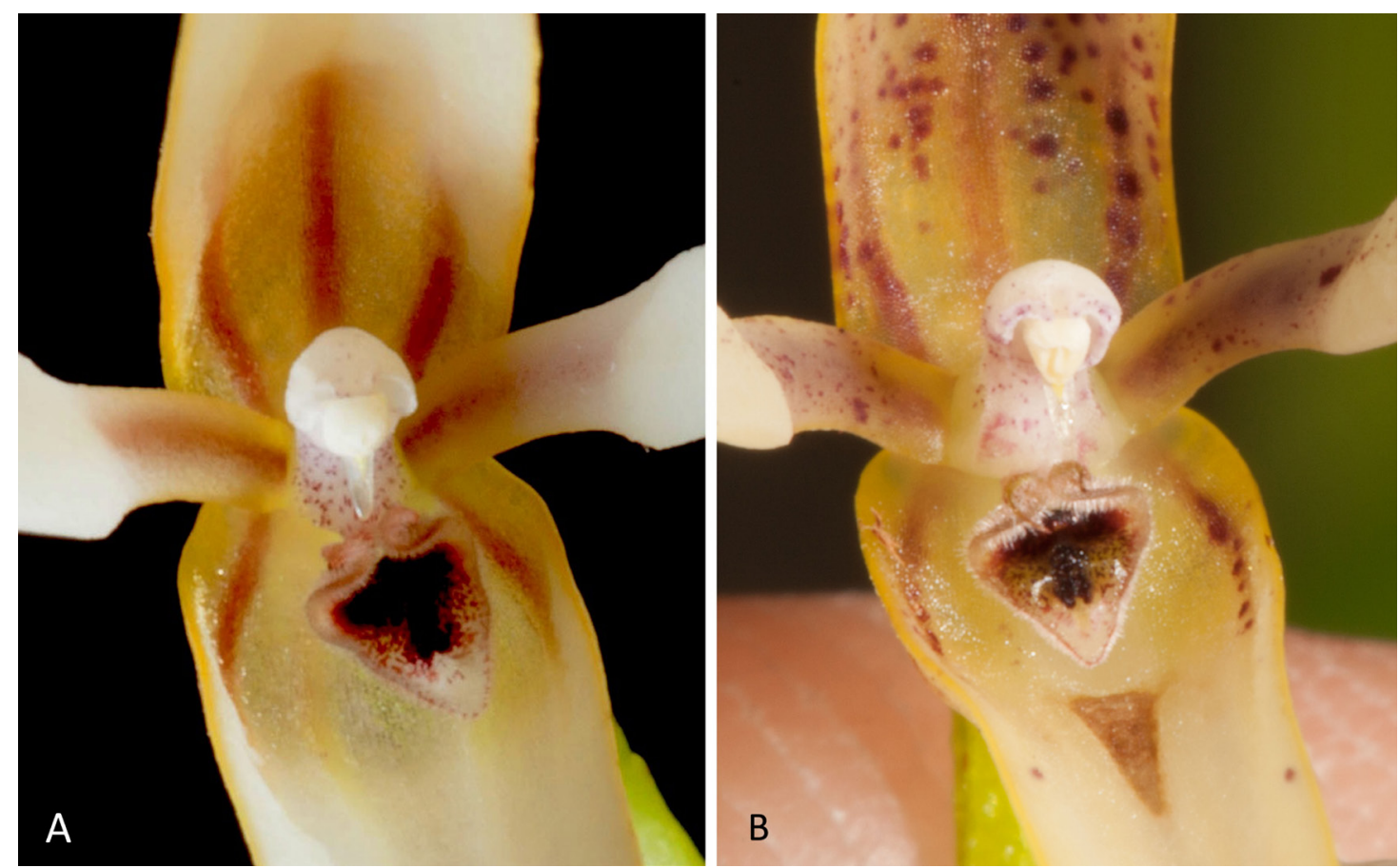

FIGURE 19. Color forms of Pleurothallis manningiana: A. cream with brown stripes (M. Wilson \& J.Portilla PL0931); and B. cream with brown stripes and chestnut spots (plant from Equaflor-A). Photos by Wilson.

in P. arietina and white in $P$. nelsonii); the degree of openness of the flowers or sepal angle (wide open or $\sim 70-90^{\circ}$ in $P$. manningiana $v s$. partially open or $\sim 50-$ $70^{\circ}$ in P. arietina and P. nelsonii); the surface texture of the flowers (smooth in P. manningiana vs. verrucose in $P$. arietina and $P$. nelsonii).

Plant medium, to $\sim 27 \mathrm{~cm}$ tall, epiphytic, caespitose. Roots slender, densely fasciculate; Ramicauls 13.5-20.0 cm long, 2.5-3.0 mm wide below leaf, erect, slender, sharply ancipitous, enclosed by papery basal sheath. Leaves erect to suberect, ovate, acute, cuneate, 5.3-6.9 $\times 2.0-2.8 \mathrm{~cm}$, sessile, entire, coriaceous. Inflorescence fascicle of solitary, successive flowers, borne from reclining spathaceous bract at base of leaf, $5.5-7.5 \mathrm{~mm}$ long; ovary lightly rugose, $4 \mathrm{~mm}$ long. Dorsal sepal offwhite or cream to pale yellow with pale brown to darker brown stripes along veins, ovate-triangular, subacute, concave, $12.5 \times 2.4 \mathrm{~mm}$, glabrous, fleshy, carinate, three-veined. Lateral sepals off-white or cream to pale yellow with pale brown to darker brown stripes along veins, completely connate into an transversely-ovate, concave synsepal, subacute, $11.5 \times 2.7 \mathrm{~mm}$, glabrous, five-veined. Petals off-white or cream to pale yellow, suffused with brown towards base, linear-lanceolate, acute, obtusely angled in the lower margin, $12.0 \times 1.2$ $\mathrm{mm}$, entire, glabrous, one-veined, fleshy. Lip white, suffused with chestnut mottling denser toward base, three-lobed, $1.8 \times 1.3 \mathrm{~mm}$ (unexpanded), attached to column by flexible strap, middle lobe triangular, thick, densely pubescent, acute, glabrous medially adaxially with a pair of small calli just above the base of the basal lobes, cavity just below the round apice, basal lobes narrowly-triangular, densely pubescent on outer margin, erect, tips folded outwards, base elevated, subtruncate, hinged behind a conical callus above base of column. Column white, stippled with pink-red, terete, densely papillose, $2.8 \times 1.75 \mathrm{~mm}$, anther and stigma sub-apical. Capsule not seen.

Additional material studied: Ecuador: Purchased from Equaflor-A as $P$. crocodiliceps by Jon Werner and flowered in cultivation in Washington state, $M$. Wilson and J. Werner PL1000, June 7, 2017 (paratype: COCO!). Peru: Amazonas: Leymebamba; El NegroCordillera de Yasgolga, 1300 m, October 2015, Marcos Salas 128 (paratype: USM!). P. crocodiliceps Rchb.f. (holotype: W!); P. arietina Ames (holotype: AMES!); 

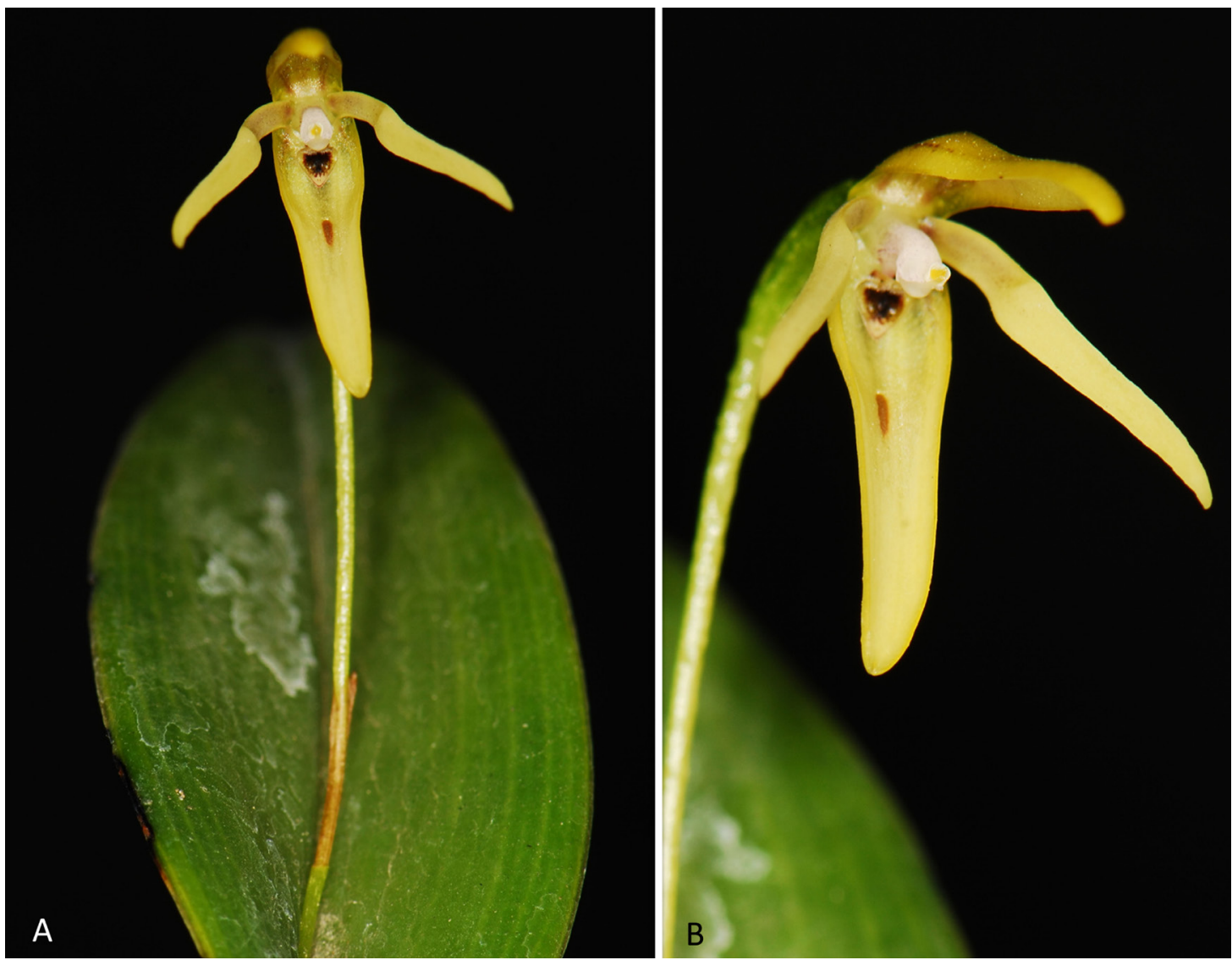

Figure 20. Color variant of Pleurothallis manningiana in situ on Guamote-Macas road, Morona Santiago, Ecuador: A. Flower (front view); and B. flower (3/4 view). Photos by Tobar.

P. nelsonii Ames (holotype: AMES!); and P. microchila (holotype: F!).

Eтymology: Named to honor Steve Manning of the U.K., creator of the R.H.S. National Pleurothallid Collection, now housed at Chester Zoo, U.K., for mentorship and support to first author Wilson and contributions to ex situ conservation of Pleurothallidinae.

Distribution and habitat: In Peru, collected from El Negro-Cordillera de Yasgolga, Leymebamba, Amazonas at $\sim 1300 \mathrm{~m}$. In Ecuador, photographed on the Guamoteto-Macas road, southeast of Guamote, Province of Morona Santiago, Ecuador, without elevation or habitat information by Francisco Tobar Suárez.

Conservation status: Pleurothallis manningiana is relatively secure in situ due to the fairly wide distribution from central Ecuador to northern Peru. Ex situ it is present in the commercial collections of
Equaflor-A and Ecuagenera, in Ecuador, and private collections in North America, though the genetic diversity of these collections is probably low.

Pleurothallis kelsoi Mark Wilson, B.T.Larsen \& J.Portilla, sp. nov. (Figs. 21-22).

TYPE: Ecuador. Flowered in cultivation at Ecuagenera, Gualaceo, Ecuador, without collection data, November 2015, M. Wilson \& J. Portilla PL0973 (holotype: HA!).

Pleurothallis kelsoi is somewhat similar to $P$. solium Luer and P. caniceps Luer. P. kelsoi is easily distinguished from $P$. solium by the lip (fleshy, minutely pubescent, 3-lobed, with deep cavity in disc in P. kelsoi vs. fleshy, glabrous, 4-lobed, with central depression in $P$. solium). $P$. kelsoi is easily distinguished from $P$. caniceps by the lip (pandurate, with deep cavity in disc in P. kelsoi vs. triangular and "lightly cleft medially" in P. caniceps (Luer 1989)). 


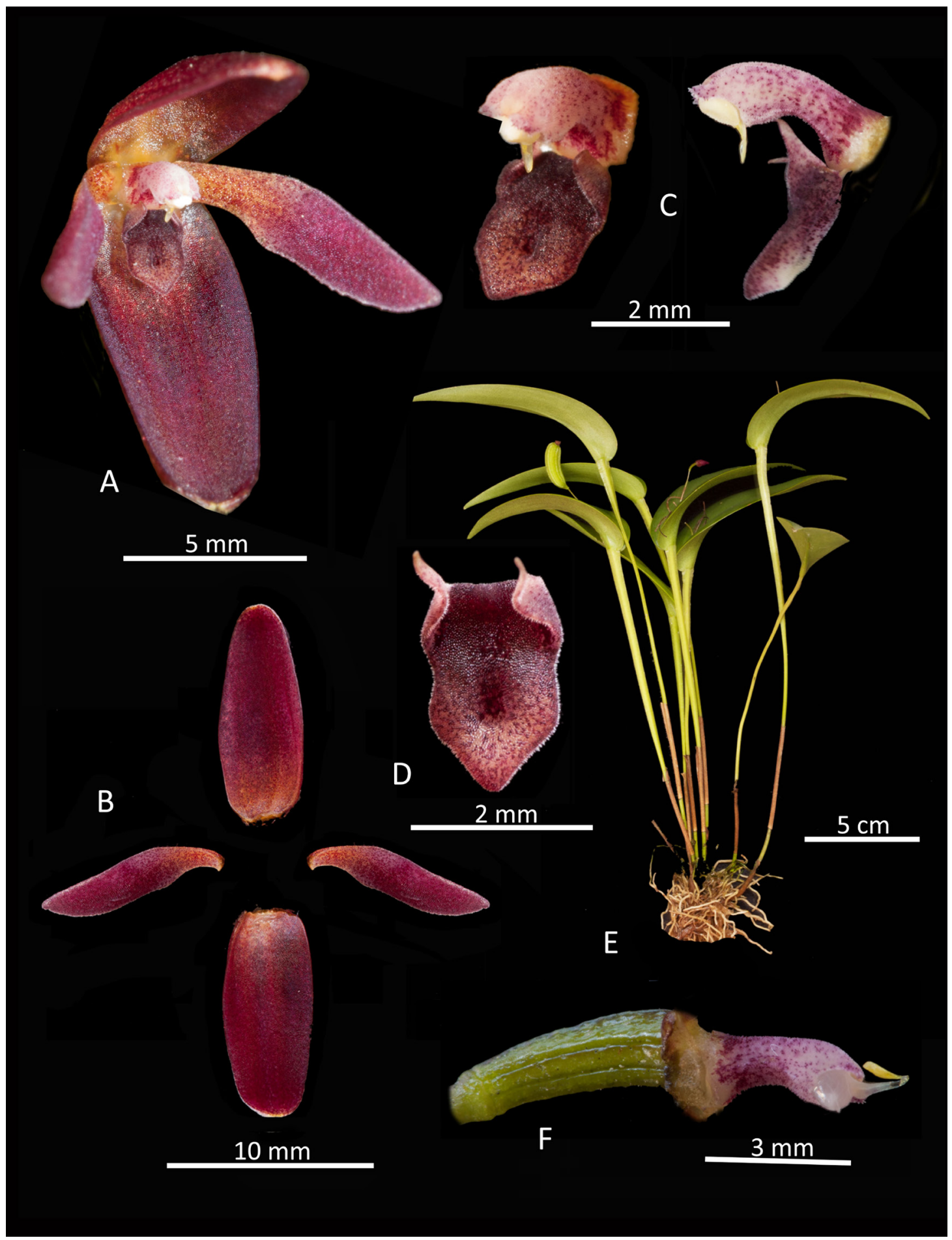

FIgure 21. Lankester composite digital plate of Pleurothallis kelsoi: A. whole flower (3/4 view); B. floral dissection; C. column and lip (3/4 view and side view); D. lip (top view); E. whole plant; and F. ovary and column. LCDP prepared by Wilson from holotype M. Wilson \& J.Portilla PL0973. 

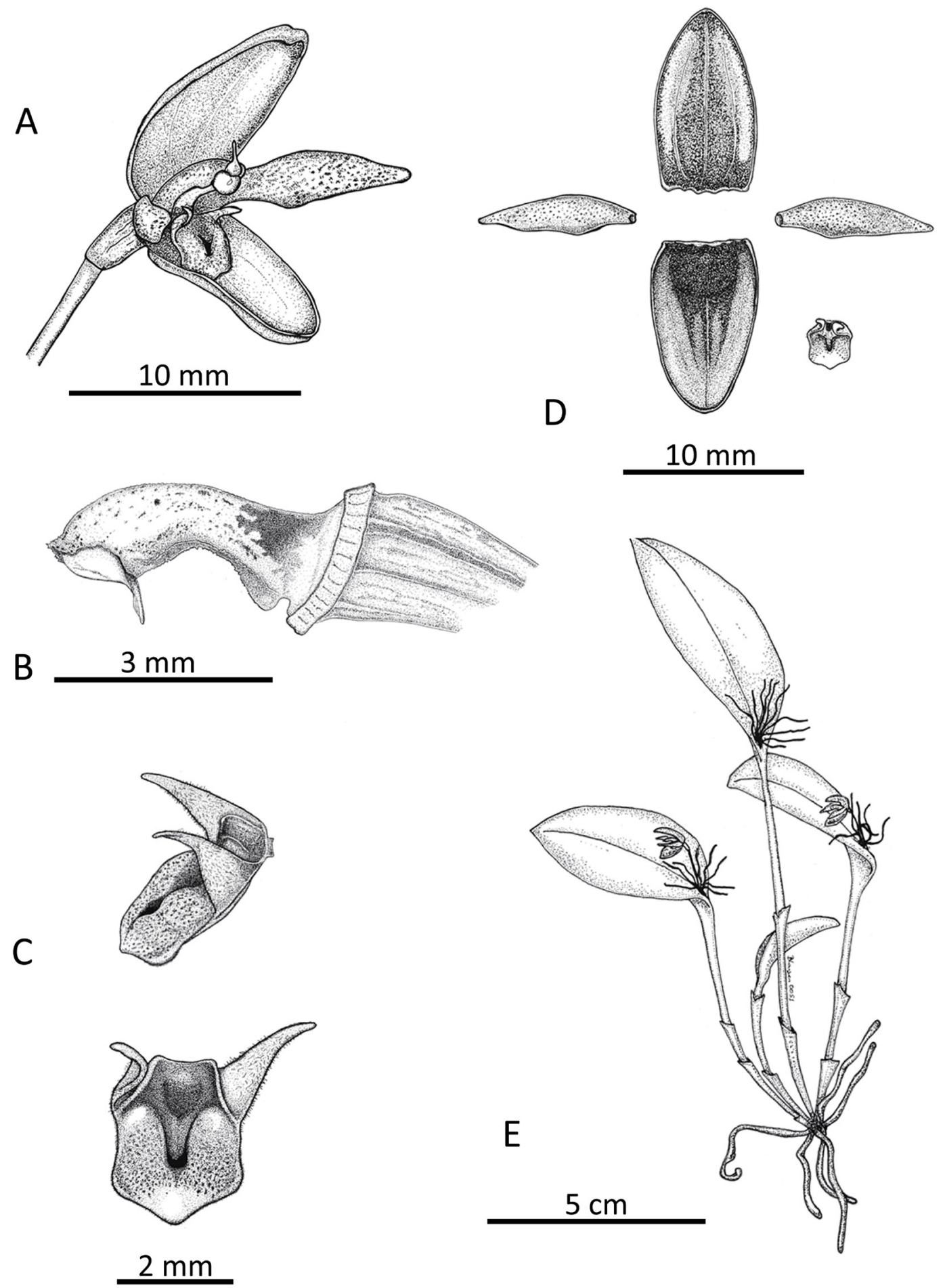

FIGURE 22. Drawing of Pleurothallis kelsoi: A. whole flower (3/4 view); B. column; C. lip (side view); D. floral dissection; and E. whole plant. Drawing prepared by Larsen from holotype M.Wilson \& J.Portilla PL0973. 
Plant medium, to $\sim 20 \mathrm{~cm}$ tall; epiphytic, caespitose. Roots slender, densely fasciculate. Ramicauls erect, slender, ancipitous, alate, $21.5-23.3 \mathrm{~cm}$ long, 5-6 mm wide below leaf, sheath at base, $11 \mathrm{~mm}$ long. Leaves erect to suberect, ovate, acute, cuneate, $5-11 \mathrm{~cm} \times 2.0$ $3.6 \mathrm{~cm}$, sessile, entire, rigid, coriaceous. Inflorescence fascicle of solitary, successive flowers, borne from a reclining spathaceous bract at base of leaf; pedicel 4 mm long; ovary sub-carinate, 3-4 mm long. Dorsal sepal burgundy, ovate-triangular, subacute, concave, 9.6-10.0 × 5.0-5.3 mm, carinate, entire, glabrous, 3-veined, fleshy. Lateral sepals burgundy, completely connate into an ovate, concave synsepal, obtuse, 9.5$10.0 \mathrm{~mm} \times 4.0-5.4 \mathrm{~mm}$, entire, glabrous, fleshy. Petals burgundy, linear-lanceolate, terete, obtusely angled in the lower margin, acute, $8.2-9.0 \times 2.0-2.2 \mathrm{~mm}$, minutely pubescent, fleshy. Lip burgundy heavily mottled on white background, minutely pubescent, threelobed, $2.2-3.0 \mathrm{~mm} \times 1.5-2.0 \mathrm{~mm}$ wide unexpanded, attached to column by flexible strap, middle lobe subpandurate, thick, microscopically pubescent, obtuse, sulcate medially below anterior half, cavity near apice, basal lobes narrowly-triangular, densely pubescent, erect, tips folded outwards, base elevated, subtruncate, hinged basally and beneath a conical callus above base of column. Column white with burgundy-purple spots increasing in density toward base, terete, $3.4 \times 0.7 \mathrm{~mm}$, the anther and stigma subapical. Capsule stout, $19.5 \times$ $6 \mathrm{~mm}$.

AdDitional MATERIal StUdied: Purchased from Ecuagenera as $P$. crocodiliceps "red" and flowered in cultivation at Colorado College, October 2015, M. Wilson \& J. Portilla PL0594 (paratype: COCO!). P. crocodiliceps Rchb.f. (holotype: W!); P. arietina Ames (holotype: AMES!); P. nelsonii Ames (holotype: AMES!); and P. microchila (holotype: F!).

Etymology: Named to honor recently deceased Primula systematist, botanist of southwestern U.S. flora, evolutionary biologist, admired teacher of undergraduate students, and esteemed colleague of Mark Wilson, Professor Sylvia 'Tass' Kelso of Colorado College.

NotE: To our knowledge this species has not been observed in situ in Ecuador, Colombia or Peru. Therefore, there exists the possibility that it is an unintentional greenhouse hybrid, perhaps between $P$. solium and a white-flowered member of the $P$. arietina-P. nelsonii complex. However, we believe that the characteristics of $P$. kelsoi are sufficiently distinct from the other species of subgenus Ancipitia to make it unlikely to be an hybrid. We intend to further investigate $P$. kelsoi through DNA sequencing and pollination experiments to attempt to recreate the species, and we plan to seek in situ populations.

Discussion. Prior to this study, P. crocodiliceps was considered to be a single widely distributed, variable species united by a "morphologically stable" lip (Luer 1989). However, detailed morphological examination of the lip of the first three species described herein, $P$. wielii, $P$. andreae and $P$. manningiana, revealed greater morphological variation than would be typical of a single species within Pleurothallis. It was apparent, therefore, that rather than a single widely distributed, variable species, there existed a previously unrecognized species complex. Also prior to this study, P. crocodiliceps had been assumed to have a minute, pubescent and trilobed lip, with the two basal lobes forming forwardpointing "horns", like those in $P$. arietina and $P$. nelsonii. However, detailed examination of the holotype of $P$. crocodiliceps from the Herbarium of the Natural History Museum of Vienna (W) revealed that the lip, though minute, was distinctly different from this. So, while $P$. arietina, $P$. nelsonii and $P$. microchila had been considered synonyms of $P$. crocodiliceps (Luer 1989, WCSP 2017), it is now apparent that $P$. crocodiliceps represents an unrelated species in subgenus Ancipitia. Therefore, rather than a single widely distributed, variable $P$. crocodiliceps (Luer 1989), we recognize the $P$. arietina-P. nelsonii species complex.

If we define the $P$. arietina- $P$. nelsonii species complex morphologically, as species possessing a minute, pubescent, tri-lobed lip, where the two basal lobes form either forward-pointing "horns" or "ears", and where the central lobe possesses an apical cavity, then the current members would be: $P$. andreae, P. arietina, P. kelsoi, P. microchila, P. nelsonii, $P$. onagriceps, $P$. renieana, $P$. wielii and possibly $P$. caniceps. The complex as currently proposed does not contain $P$. crocodiliceps in which, we now know, the lip is distinctly different (Fig. 5b). Further, the first author believes, that there may be a substantial number of "cryptic" species remaining to be described. 
TABle 2. Comparison of dimensions of Pleurothallis arietina, P. nelsonii and P. microchila. (P. arietina and P. nelsonii ${ }^{\mathrm{a}}$ from Ames (1923); P. arietina ${ }^{\mathrm{b}}$ from Luer (1977); P. nelsonii ${ }^{\mathrm{b}}$ from Soto-Arenas \& Solano-Gomez (2007); P. microchila from Williams (1967); ----- = measurements not included in description.)

\begin{tabular}{|c|c|c|c|c|c|}
\hline Species & $P$. arietina ${ }^{a}$ & $P$. arietina ${ }^{b}$ & P. nelsonifa & P. nelsonit & P. microchila \\
\hline Whole plant $(\mathrm{cm})$ & ------------- & ------------- & ------------- & 20 & 15 \\
\hline Ramicaul (cm) & $20-25$ & $10-20$ & 12 & $9-20$ & $5-12$ \\
\hline Leaf $(\mathrm{cm})$ & $8.5 \times 3.5$ & $6-9 \times 3-4$ & $7 \times 2$ & $8-10 \times 2.8-4$ & $6-10 \times 2-3$ \\
\hline Dorsal sepal $(\mathrm{mm})$ & 8 & $10-11 \times 4.5$ & 10 & $11-11.5 \times 4$ & $10 \times 3$ \\
\hline Synsepal (mm) & $9 \times 3$ & $8-10$ x 4-5 & $10 \times 3$ & $10-10.5 \times 3.6-4$ & $10 \times 4$ \\
\hline Petals (mm) & $8 \times 1$ & ------------- & $8.5 \times 1$ & $9.6-9.8 \times 1.5$ & $7.5 \times 1$ \\
\hline Lip (mm) & 2 & ------------- & 2 & $1.5 \times 1.3$ & $1.3 \times 0.9$ \\
\hline Column (mm) & 3 & ------------- & 3 & $3-3.2 \times 1$ & -------------- \\
\hline
\end{tabular}

Unfortunately, most of the species in this group cannot be distinguished based upon vegetative characteristics since there is significant overlap in vegetative morphology and dimensions (Tables 1 and 2). The species, however, can be distinguished by the following floral characteristics: aspect of the flower (horizontal, pendent, downward-facing); degree to which flower opens (partial, fully); color of the flower, including the distribution of the secondary color spotting or suffusing the primary/base color; surface texture of the petals (presence or absence of verrucae or "warts"); sepal width; petal thickening; column length and shape/ orientation; modified column-foot position (close to "strap" connecting labellum or more distant); lip size (length and width); pubescence (degree, distribution, length of "hairs"); basal lobes (length, orientation and color); and cavity in central lobe (position, degree of pubescence and size). To provide additional support for species boundaries DNA sequence information will be critical. Based on our preliminary analyses (Wilson et al. unpubl. data) while some of the species may be distinguished utilizing internal transcribed spacer (ITS) sequences alone, others will require more variable plastid regions such as 3' $y c f$, trnL-F and trnH-psbA.

There is one curious plant that may represent an example of a species in the complex that can be distinguished from the other species by vegetative characteristics. Pleurothallis sp. "EcoMinga", currently being described by Wilson et al. (unpubl. data), has flowers with the typical $P$. arietina-P. nelsonii-type lip, but the fascicle of single-flowered peduncles arise not from the base of the leaf as in all other species of the complex, but from near the apex of the leaf as in members of subgenus Scopula. Further investigation will be required to determine whether this species represents a member of the $P$. arietina- $P$. nelsonii complex that has evolved a terminal inflorescence or a species of subgenus Scopula that has evolved a $P$. arietina-P. nelsonii-type lip.

The $P$. arietina- $P$. nelsonii species complex is distributed from southern Mexico through Central America, into the Andean countries of Venezuela, Colombia, Ecuador and Peru, as far south as Bolivia (under listing for P. crocodiliceps, Luer 1989). It should, in retrospect, have been apparent that the probability of a single species, $P$. crocodiliceps, being distributed from Mexico to Bolivia was highly unlikely. Few if any Pleurothallis species exhibit a distributional range of this magnitude; indeed, it is probably an indication that a widely distributed "variable" species, for example Pleurothallis bivalvis Lindl., is in fact a collection of morphologically similar species. The existence of the species complex has significant consequences for conservation, since rather than protecting a single species, $P$. crocodiliceps, it will now be necessary to consider the conservation status of multiple species in several different countries.

Although in this study we have demonstrated that $P$. arietina, $P$. nelsonii and $P$. microchila are not synonyms of $P$. crocodiliceps and we have included all three species epithets in the $P$. arietina- $P$. nelsonii species complex, we do not know yet whether $P$. arietina, $P$. nelsonii and P. microchila themselves represent distinct species. Studies are underway to more fully characterize 
P. nelsonii (Wilson \& Solano-Gómez, unpubl. data) and P. microchila (Wilson \& Archila, unpubl. data), so that these species can be compared with each other and with P. arietina and other related species occurring in Costa Rica and Panama being studied by Lankester Botanical Garden. At this point, however, we must consider them distinct until demonstrated otherwise.

One remaining question is the identity of $P$. crocodiliceps. While the vegetative characteristics (Fig. 1) and the morphology of the flower (Fig. 5a) indicate that the species belongs in subgenus Ancipitia, the lip (Fig. 5b) is distinct from any extant species observed to date. It will be necessary to explore plant collections and remaining forest in the Agua de la Virgen area of Norte de Santander, Colombia, in order to try to track down living specimens of the species.

One cannot leave a discussion of the P. arietina-P. nelsonii species complex floral morphology without briefly commenting on the bizarre nature of the lip. Luer (1975a) commented rather fancifully that maybe "it is supposed to resemble a minute insect or spider to entice a predator into the jaws of the crocodile-flower to perform the act of cross-pollination". More seriously, Luer (1989) speculated that it "undoubtedly acts as some kind of bait for a pollinator". While in situ pollination of species of the P. arietina-P. nelsonii species complex has not yet been observed, based upon the morphology, we hypothesize that these species are pollinated by sexual deceit, the lip resembling the female of a fly with which the male of the species attempts to copulate (Dupree \& Wilson 2016). Probably the narrow, delicate "strap" by which the lip connects to the column (visible behind the modified column-foot in Fig. 17d) allows for labellar motility, perhaps mimicking the movement of a receptive female fly. We further speculate that the cavity in the central lobe of the lip has evolved to receive the abdomen of the male fly during copulation and hence, we propose the term "copulatorium" to refer to this cavity. Moreover, the morphological differences in the lips of the species in this complex strongly suggest to us the possibility that each species in the $P$. arietina- $P$. nelsonii species complex is pollinated by just one or very few species of fly, as is thought to be the case in other orchid genera in which pseudocopulation occurs. Such suppositions will clearly have to be tested with field observations and DNA barcoding of pollinators, but the morphology of the flowers in the P. arietina-P. nelsonii species complex is strongly suggestive and alternative hypotheses for this morphology are hard to imagine. In the future we also plan to study volatile organic chemicals emitted from flowers of these species using GC-MS to determine whether chemicals with pheromone-like activity are produced and to determine whether individual species exhibit distinct volatile chemical profiles.

Conclusions. Prior to this study the botanical community recognized a single widely distributed variable species, P. crocodiliceps. As a consequence of this study, we now recognize instead a widely distributed species complex consisting of species possessing flowers with a characteristic lip. Since P. crocodiliceps does not have this type of lip, we refer to the group of species as the $P$. arietina- $P$. nelsonii complex. Studies are ongoing to further characterize the species within the complex based on floral morphology, DNA sequences and chemical profiles.

ACKNOWLEDGEMENTS. The authors are grateful to Colorado College for research funding for Wilson and Dupree; to Dr. Ron Hathaway for assistance with SEM and for suggesting the term "copulatorium"; to Ecuagenera for access to their plant collections and to members of the Portilla family for their warm hospitality; to Equaflor-A for access to their plant collection and to Gilberto Merino for assistance; to Orquídeas del Valle for access to their plant collection and to Andrea Niessen for assistance; to Luis Baquero of Quito Botanic Garden for preparing herbarium specimens; Rafaella Ansaloni at the herbarium of Universidad del Azuay, Cuenca, Ecuador (HA) for receiving herbarium specimens; to staff of the Vienna Natural History Museum, Vienna, Austria (W) for scanning herbarium specimens of P. crocodiliceps; to Adam Karremans and Diego Bogarín for instruction in preparation of LCDPs; to Gustavo Romero at Harvard University Herbarium for information about the $P$. crocodiliceps herbarium sheet at that location; to Alberto Guerrero for in situ observation data and photographs of $P$. andreae; and to the Editor and the anonymous reviewers for suggestions on the manuscript.

Author Contributions. Authors following the senior author are listed alphabetically and not by importance or magnitude of contribution. Wilson initiated the project, recognized the existence of a P. arietina-P. nelsonii species complex, prepared the LCDPs, arranged the SEM micrographs and wrote the Introduction, Methods, Results and Discussion; Larsen prepared all the species illustrations and descriptions; Dupree generated the SEM micrographs; and Löckher, Niessen, Portilla, Salas Guerrero, Suárez and Tobar-Suárez made collections, provided access to collections, or provided plant material or photographs. 


\section{LiterATURE CITED}

Ames, O. (1923). Schedulae Orchidianae. 5. New or noteworthy orchids from central America and the Philippine Islands. Earnshaw Press.

Bennett, D. E. \& Christenson, E. A. (1993). Icones Orchidacearum Peruvianum. St. Louis, MO, U.S.A.: Missouri Botanical Gardens Press.

Dodson, C. H. (2003). Native Ecuadorian Orchids, Volume 4: Oncidium to Restrepiopsis. Sarasota, FL, U.S.A.: Dodson Trust.

Dodson, C. H. \& Dodson, P. M. (1980). Orchids of Ecuador, Series I, Fascicles 1-4, Icones Plantarum Tropicarum. Sarasota, FL, U.S.A.: The Marie Selby Botanical Gardens.

Dodson, C. H. \& Dodson, P. M. (1982). Orchids of Ecuador, Series I, Fascicle 5, Icones Plantarum Tropicarum. Sarasota, FL, U.S.A.: The Marie Selby Botanical Gardens.

Dodson, C. H. \& Dodson, P. M. (1989). Orchids of Ecuador, Series II, Fascicles 5-6, Icones Plantarum Tropicarum. Sarasota, FL, U.S.A.: Missouri Botanical Garden.

Dunsterville, G. C. K. \& Garay, L. A. (1979). Orchids of Venezuela: An Illustrated Field Guide. Vol. P-Z. U.S.A.: Harvard University Press.

Dunsterville, G. C. K. (1986). Descriptions of orchids not in Venezuelan Orchids Illustrated. Lindleyana, 1(4), 221-355.

Dupree, K. \& Wilson, M. (2016). Floral micromorphology and evolution of pollination by sexual deceit in Pleurothallis R.Br. (Orchidaceae; Pleurothallidinae) subgenera Ancipitia and Scopula. Abstract, Annual Meeting Botanical Society of America.

Escobar, R. (1994). Native Colombian Orchids, vol. 3: Maxillaria-Ponthieva. Medellín, Colombia: Compañia Litográfica Nacional S.A.

Escobar, R. (2006). Native Colombian Orchids, vol. 6, supplement: Leucochyle-Zootrophion. Medellín, Colombia: Compañia Litográfica Nacional S.A.

Foldats, E. (1970). Flora de Venezuela, volumen XV, segunda parte. Caracas, Venezuela: Instituto Botánico.

Luer, C. A. (1975a). Icones Pleurothallidinarum: Pleurothallis of Ecuador (Orchidaceae). Selbyana, 1(1), 56-100.

Luer, C. A. (1975b). Icones Pleurothallidinarum (Orchidaceae): Pleurothallis of Ecuador II. Selbyana, 1(2), 172-195.

Luer, C. A. (1975c). Icones Pleurothallidinarum (Orchidaceae): Pleurothallis of Ecuador III. Selbyana, 1(3), 220-303.

Luer, C. A. (1976). Icones Pleurothallidinarum: Miscellaneous species of Pleurothallis. Selbyana, 3(1-2), 38-201.

Luer, C. A. (1977). Icones Pleurothallidinarum
(Orchidaceae): Miscellaneous species in the Pleurothallidinae. Selbyana, 3(3-4), 203-407.

Luer, C.A. (1986). Icones Pleurothallidinarum III: Systematics of Pleurothallis. Monographs in Systematic Botany, 20, 1-109.

Luer, C. A. (1989). Icones Pleurothallidinarum VI. Systematics of Pleurothallis subgenus Ancipitia, subgenus Scopula and Trisetella (Orchidaceae). Monographs in Systematic Botany, 31, 1-125.

Luer, C. A. (2004). Icones Pleurothallidinarum XXVI. Pleurothallis subgenus Acianthera and three allied subgenera. A second century of new species of Stelis of Ecuador. Epibator, Ophidion, Zootrophion. Monographs in Systematic Botany, 95, 1-265.

Luer, C. A. (2009). Miscellaneous new species in the Pleurothallidinae (Orchidaceae). Selbyana, 30(1), 1-71.

Luer, C. A. (2011). Miscellaneous new species in the Pleurothallidinae (Orchidaceae) excluding species from Brazil. Harvard Papers in Botany, 16(2), 311-360.

Luer, C. A. \& Thoerle, L. (2013). Miscellaneous new species in the Pleurothallidinae (Orchidaceae). Harvard Papers in Botany, 18(2), 173-196.

Pridgeon, A. M. \& Chase, M. W. (2001). A phylogenetic reclassification of Pleurothallidinae (Orchidaceae). Lindleyana, 16, 235-271.

Pridgeon, A. M., Cribb, P. J., Chase, M. W. \& Rasmussen, F. N. (2005). Genera Orchidacearum. Vol. 4. Epidendroideae (Part one) (pp. 385-390). Oxford, U.K.: Oxford University Press.

Pridgeon, A. M., Solano, R. \& Chase, M. W. (2001). Phylogenetic relationships in Pleurothallidinae (Orchidaceae): Combined evidence from nuclear and plastid DNA sequences. American Journal of Botany, 88, 2286-2308.

Reichenbach, H. G. (1885). Wagener's Orchideen aus Ocaña. Bonplandia, 3, 65-73.

Schweinfurth, C. (1959). Orchids of Peru. Fieldiana Botany, 30(2), 261-531.

Schweinfurth, C. (1970). First Supplement to the Orchids of Peru. Fieldiana Botany, 33, 1-85.

Soto Arenas, M.A. \& Solano, R. (2003). Pleurothallis nelsonii Ames, PL. 640. In: Hágsater, E. \& Salazar, G. A. (Eds.), Icones Orchidacearum fascicles $2 \& 3$ : Orchids of Mexico fascicles parts $5 \& 6$. Mexico City: Instituto Chinoin A.C.

Williams, L. O. (1967). Tropical American Plants VIII. Fieldiana Botany, 31, 247-269.

Wilson, M., Baquero, L., Dupree, K., Jiménez, M. M., LeBlanc, C. M., Merino, G., Portilla, J., Salas Guerrero, M., Tobar Suárez, F. \& Werner, J. D. (2016). Three new species of Pleurothallis (Pleurothallidinae; 
Orchidaceae) in subsection Macrophyllae-Fasciculatae from northern South America. Lankesteriana, 16(3), 349-366. Doi: http://dx.doi.org/10.15517/lank. v16i3.27314

Wilson, M., Belle, C., Dang, A., Hannan, P., Kenyon, C., Low, H., Stayton, T. \& Woolley, M. A. (2011). A phylogenetic analysis of the genus Pleurothallis, with emphasis on Pleurothallis subsection MacrophyllaeFasciculatae, using nuclear ITS and chloroplast DNA sequencing. Lankesteriana, 11(3), 369. Doi: http:// dx.doi.org/10.15517/lank.v11i3.18304

Wilson, M., Belle, C., Dang, A., Hannan, P., Kellogg, L.,
Kenyon, C., Low, H., Mochizuki, A., Nguyen, A., Sheade, N., Shan, L., Shum, A., Stayton, T., Volz, C., Vosburgh, B., Wellman, H. \& Woolley, M. A. (2013). Preliminary phylogenetic analysis of Pleurothallis sensu lato based upon nuclear and plastid sequences. Lankesteriana, 13(1-2), 139. Doi: http://dx.doi. org/10.15517/lank.v0i0.11568

World Checklist of Selected Plant Families, WCSP (2017). Facilitated by the Royal Botanic Gardens, Kew. Retrieved from http://apps.kew.org/wcsp/

Zelenko, H. \& Bermúdez, P. (2009). Orchids: Species of Peru. Quito, Ecuador: Imprenta Mariscal. 
LANKESTERIANA 